\title{
Cetacean occurrence offshore of Washington from long-term passive acoustic monitoring
}

\author{
Ally Rice ${ }^{1}$ (D) Amanda J. Debich ${ }^{1,2} \cdot$ Ana Širović $^{1,3} \cdot$ Erin M. Oleson $^{4} \cdot$ Jennifer S. Trickey ${ }^{1} \cdot$ Leah M. Varga $^{1}$. \\ Sean M. Wiggins ${ }^{1} \cdot$ John A. Hildebrand ${ }^{1} \cdot$ Simone Baumann-Pickering ${ }^{1}$
}

Received: 20 January 2021 / Accepted: 6 July 2021 / Published online: 24 July 2021

(c) The Author(s) 2021

\begin{abstract}
A variety of cetacean species inhabit the productive waters offshore of Washington State, USA. Although the general presence of many of these species has been documented in this region, our understanding of fine-scale habitat use is limited. Here, passive acoustic monitoring was used to investigate the spatial and temporal distributions of ten cetacean species at three locations offshore of Washington. Between 2004 and 2013, a total of 2845 days of recordings were collected from sites on the continental shelf and slope, and in a submarine canyon. Acoustic presence was higher for all species at sites farther offshore. Detections were highest during the fall and winter for blue (Balaenoptera musculus), fin (B. physalus), and humpback whales (Megaptera novaeangliae), likely related to reproductive behavior, while minke whales (B. acutorostrata) were only detected on two days. Odontocetes showed temporal separation, with sperm whale (Physeter macrocephalus) detections highest in spring, Risso's (Grampus griseus) and Pacific white-sided dolphins (Lagenorhynchus obliquidens) highest in summer, and Stejneger's beaked whales (Mesoplodon stejnegeri), Cuvier's beaked whales (Ziphius cavirostris), and the BW37V signal type highest in winter or spring. There was interannual variation in detections for most mysticete species, which may be linked to oceanographic conditions: blue and fin whale detections increased during 2007 and 2008, and fin and humpback whale detections increased in 2011. These results inform our understanding of cetacean behavior and habitat use in this region and may aid in the development of conservation strategies suited to the dynamic conditions that drive cetacean distribution.
\end{abstract}

Responsible Editor: D.E. Crocker.

Reviewed by: undisclosed experts.

Ally Rice

arice@ucsd.edu

1 Scripps Institution of Oceanography, University of California San Diego, La Jolla, CA 92093, USA

2 Present Address: Rosenstiel School for Marine and Atmospheric Science, Cooperative Institute for Marine and Atmospheric Studies, University of Miami, Miami, FL 33149, USA

3 Present Address: Texas A\&M University at Galveston, 200 Seawolf Parkway, Galveston, TX 77554, USA

4 Pacific Islands Fisheries Science Center, National Oceanic and Atmospheric Administration, Honolulu, HI 96818, USA

\section{Introduction}

The continental shelf and nearby offshore waters of Washington State make up a highly dynamic and diverse pelagic ecosystem. In this area, the southward-flowing California Current undergoes large seasonal fluctuations that contribute to upwelling, which is strongest in spring and summer (Huyer et al. 1979) and brings nutrient-rich waters to the surface, enhancing productivity and subsequently supporting higher trophic levels.

Many species of cetaceans are drawn to these nutrientrich waters. Blue (Balaenoptera musculus), fin (B. physalus), humpback (Megaptera novaeangliae), and minke whale (B. acutorostrata), as well as Risso's (Grampus griseus) and Pacific white-sided dolphins (Lagenorhynchus obliquidens) are some of the species found along the continental shelf and slope (Green et al. 1992, Calambokidis and Barlow 2004, Barlow and Forney 2007, Forney 2007, Bailey et al. 2009, Oleson et al. 2009, Schorr et al. 2010, Calambokidis et al. 2015). Deep-water habitats are used by sperm (Physeter 
macrocephalus) and beaked whales (Green et al. 1992, Barlow and Forney 2007). Sightings are typically higher from spring to fall (Green et al. 1992, Watkins et al. 2000, Stafford et al. 2001, Calambokidis et al. 2015) when many of these species can take advantage of productive high-latitude waters to forage.

Most of the large whale species found in this region, such as blue, fin, humpback, and sperm whales, were heavily targeted by historical whaling (Gregr et al. 2000, Monnahan et al. 2014, Rocha et al. 2014) and are currently considered endangered (Carretta et al. 2020). For humpback whales, abundance in the North Pacific has been increasing (Calambokidis and Barlow 2004, Calambokidis et al. 2004, Forney 2007, Barlow et al. 2011), however, out of the three distinct population segments that can be found offshore of Washington, one is currently listed as endangered and another is threatened (Barlow et al. 2011, Bettridge et al. 2015, NOAA 2016).

Other species, such as minke whales and Risso's and Pacific white-sided dolphins, are not currently considered threatened, but they have not been well studied either (Carretta et al. 2019). Even less is known about the beaked whale species found in the region, such as Cuvier's (Ziphius cavirostris), Stejneger's (Mesoplodon stejnegeri), and Hubbs' (Mesoplodon carlhubbsi) beaked whales. Moore and Barlow $(2013,2017)$ found that the abundance of Cuvier's beaked whales was declining in the California Current Ecosystem, but that Mesoplodon abundance had increased. However, the increase in Mesoplodon abundance may have been impacted by increased temperatures (Moore and Barlow 2017) and, since identifying Mesoplodon sightings to species level is rare, it is difficult to make any sort of population assessment for Stejneger's or Hubbs' beaked whales in the region (Carretta et al. 2019).

The U.S. west coast has been the site of repeated visual marine mammal surveys (Barlow and Forney 2007). While these studies provide a general understanding of cetacean distribution, the addition of acoustic surveys can provide further insight into cetacean habitat use (Barlow and Taylor 2005, Rankin et al. 2008, Hanson et al. 2013, Vu 2015, Keating et al. 2016, Simonis et al. 2020). There can also be differences between when sightings peak and when acoustic detections peak. For example, visual sightings of fin whales, as well as catches during historic whaling, were highest during summer (Green et al. 1992, Mizroch et al. 2009), but calling peaked during winter (Moore et al. 1998, Watkins et al. 2000, Soule and Wilcock 2013), highlighting the importance of conducting both visual and acoustic surveys to fully assess the spatial and temporal distribution and habitat use of marine mammal species.

Cetaceans frequently use sound for communication, foraging, and navigation, making them prime candidates to study using passive acoustics (Mellinger et al. 2007).
Mysticetes produce distinct, low-frequency signals ranging from short sweeps to long, frequency modulated (FM) calls that allow for reliable identification of species-specific call types. Offshore of Washington, two of the call types commonly produced by blue whales are B calls and D calls. B calls are low-frequency $(20 \mathrm{~Hz})$, long-duration $(20 \mathrm{~s})$ calls that are often regularly repeated and are possibly associated with reproduction (McDonald et al. 2006, Oleson et al. 2007a). D calls are down sweeps that last several seconds and are considered a social call (McDonald et al. 2001, Oleson et al. 2007a, Lewis et al. 2018). Fin whales produce short (approximately $1 \mathrm{~s}$ duration), low-frequency calls known as $20 \mathrm{~Hz}$ calls (Watkins 1981), which are sometimes produced in long, patterned sequences that show geographic variation (Širović et al. 2009, 2017, Castellote et al. 2012, Oleson et al. 2014, Helble et al. 2020). Humpback whales produce a variety of calls, ranging from 100 to $3000 \mathrm{~Hz}$, which can be classified as song and non-song vocalizations (Payne and McVay 1971, Thompson et al. 1986, Dunlop et al. 2007, Stimpert et al. 2011, Fournet et al. 2015). Song has been recorded only from males (Winn and Winn 1978, Tyack 1981, Baker and Herman 1984, Herman et al. 2013, Herman 2017) on both breeding and feeding grounds (Mattila et al. 1987, McSweeney et al. 1989, Gabriele and Frankel 2002, Clark and Clapham 2004, Vu et al. 2012). Predominant non-song call types in the North Pacific include growls and whups-low frequency (peak frequency $<150 \mathrm{~Hz}$ ), short (1 s or less), and quiet calls, particularly relative to song (Wild and Gabriele 2014, Fournet et al. 2015, 2018). In the North Pacific, minke whales produce a fairly stereotyped call that consists of a brief pulse followed by a long, frequency and amplitude modulated component called a boing (Thompson and Friedl 1982, Rankin and Barlow 2005, Delarue et al. 2013). These calls vary between different regions, but generally have a peak frequency of approximately $1400 \mathrm{~Hz}$, an overall duration of 2-4 s, and a pulse repetition rate of either 92 or $115 \mathrm{~s}^{-1}$ (Rankin and Barlow 2005).

Odontocete species use echolocation clicks to forage, and since their clicks are typically species-specific, they can be used for species identification. The echolocation clicks produced by sperm whales generally contain energy from 2 to $20 \mathrm{kHz}$, with the majority of energy between 10 and $15 \mathrm{kHz}$ (Møhl et al. 2003). Risso's and Pacific whitesided dolphins produce broadband echolocation clicks that can be discriminated by their unique frequency banding patterns (Madsen et al. 2004, Soldevilla et al. 2008, 2017). Beaked whale echolocation signals are unique in their polycyclic structure and FM pulse upsweep. The peak frequency, spectral peaks, and inter-pulse interval of these signals vary among species and can be used for species discrimination (Johnson et al. 2004, Zimmer et al. 2005, Baumann-Pickering et al. 2013a, 2013b, Griffiths et al. 2018). 
In this study, we used species-specific cetacean call types to analyze long-term passive acoustic recordings from three locations offshore of Washington State and examine the spatial and temporal distribution of four mysticete and six odontocete species. Long-term, year-round monitoring is essential for understanding how species' distributions may be impacted by changing population levels and oceanographic conditions. With a better understanding of habitat preferences and seasonal presence, it may be possible to more effectively manage and conserve these species.

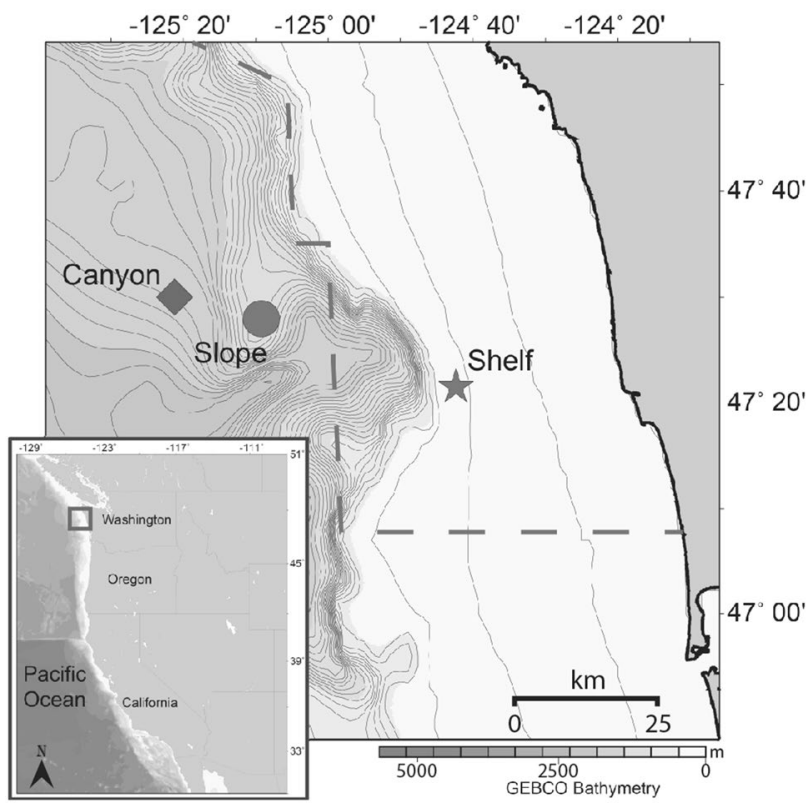

Fig. 1 Map showing the locations of deployment sites from 2004 to 2013. Grayscale shows depth in meters and thin gray lines mark $50 \mathrm{~m}$ bathymetry contours. The star, circle, and diamond represent sites Shelf, Slope, and Canyon, respectively. The broken line represents the Olympic Coast National Marine Sanctuary boundary. The gray box in the inset map of the west coast of the USA indicates the location of the study site. Map generated using Maptool, a product of seaturtle. org

\section{Methods}

\section{Data collection}

High-frequency acoustic recording packages (HARPs) were deployed across three sites off the coast of Washington (Fig. 1) on 16 occasions, in an effort to survey the acoustic presence of cetaceans within the U.S. Navy's Northwest Training Range Complex. All HARPs were deployed on the seafloor and had a calibrated hydrophone suspended 10-30 $\mathrm{m}$ above the instrument (Wiggins and Hildebrand 2007). Of the 16 HARP deployments, most sampled continuously at 80 or $200 \mathrm{kHz}$, but seven deployments had duty-cycled recordings (Table S1). The three deployment locations were selected to span a variety of habitats: site Shelf was located offshore of Cape Elizabeth, on the continental shelf at 100-150 m and within the boundary of the Olympic Coast National Marine Sanctuary, site Slope was located on the continental slope at about $600-900 \mathrm{~m}$, site Canyon was a deep offshore location in Quinault Canyon at almost 1400 m (Fig. 1, Table S1). These sites were monitored intermittently from July 2004 to August 2013 (Table S1, Fig. 2).

\section{Terminology}

A variety of methods were used to identify cetacean calls in this dataset. Hereafter, the term "detection" will only be used when generally referring to identified calls and will be further qualified when used to refer to calls identified using a specific methodology (Kowarski and Moors-Murphy 2020). Calls that were identified by human analysts will be referred to as "manual detections," while calls that were identified by a computer algorithm will be referred to as "automatic detections." For cases where calls were automatically detected and then each detection was verified by a human analyst, results will be referred to as "manually validated detections."

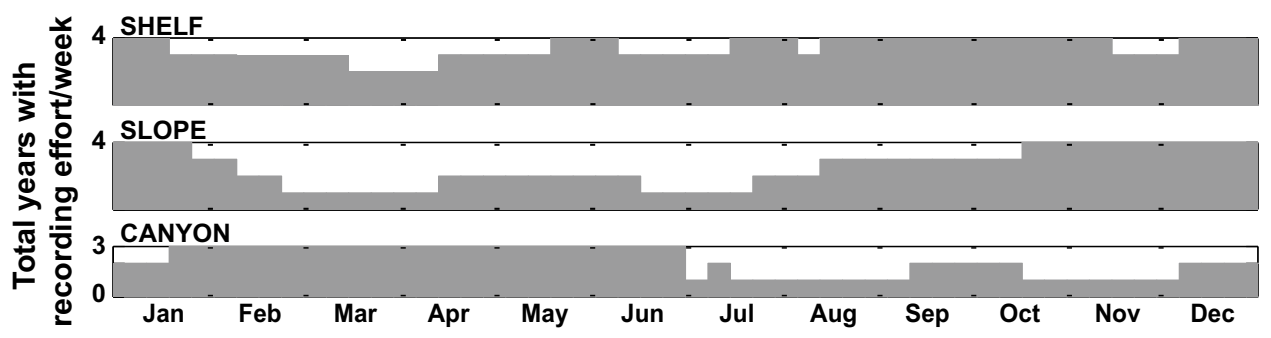

Fig. 2 The total number of years with recording effort (gray bars) during each week at each site. The weekly bins shown are the same as used in the data analysis and indicate how many years of data were averaged for a given week. Shelf had data 2004-2013, Slope had data 2004-2008, and Canyon had data 2011-2013 


\section{Call detection}

Decimated datasets were produced to allow for more effective scanning of long-term spectral averages (LTSAs) and spectrograms. For analysis of blue and fin whale calls, data were decimated to a $2 \mathrm{kHz}$ sampling frequency and for analysis of humpback and minke whale calls, data were decimated to a $10 \mathrm{kHz}$ sampling frequency. Full bandwidth recordings were used for analyzing all other call types. Data were analyzed manually, using Triton, a custom MATLAB program designed to allow for visual scans of LTSAs (Wiggins and Hildebrand 2007), or automatically, using appropriate detection algorithms. Further details on call detection are provided below for each species.

Blue whale B and D calls were detected manually for most deployments, using LTSAs with $5 \mathrm{~s}$ time average and $1 \mathrm{~Hz}$ frequency resolution. Analysts scanned LTSAs for the hourly presence of these calls and used $60 \mathrm{~s}$ spectrograms (1500 point fast Fourier transform (FFT) length, 90\% overlap) displayed from 0 to $200 \mathrm{~Hz}$ to confirm call presence. However, for data recorded from 2011 to 2013, blue whale B calls were detected automatically, using spectrogram correlation (Mellinger and Clark 2000, Širović et al. 2015). The parameters used to run this detector varied by deployment (Table S2, Table S3) since detector performance is impacted by seasonal and interannual shifts in B call frequency and abundance (McDonald et al. 2009, Širović 2016). Based on analysis from three deployment periods, the missed detection rate was $<12 \%$ and the false detection rate was $<10 \%$. The transition to using this detector was made to increase the efficiency of analyzing a large dataset, but it meant that both manual and automatic detection methods were used for this call type (Table S1). Although caution should be exercised when making comparisons within and between sites in cases where these different methods were used, B call detections from both methods were converted to hourly presence so that detections were comparable. The number of hours with call presence each day were summed and averaged over weekly and monthly bins.

The presence of fin whale $20 \mathrm{~Hz}$ calls was detected automatically using an energy detector that calculated the difference in acoustic energy between the signal $(22 \mathrm{~Hz})$ and background levels (average energy between 10 and $34 \mathrm{~Hz}$ ) in an LTSA (Širović et al. 2004, 2015, Nieukirk et al. 2012). The ratio produced is reported as a daily average and is referred to as a 'fin whale acoustic index'. This daily average was then averaged over weekly and monthly bins.

Humpback whale calls were detected manually for deployments at Shelf from August 2006 to June 2009 and were detected using an automatic detector for all other deployments (Table S1). As with blue whale B calls, the transition to an automatic detector was meant to increase the efficiency of analysis. During manual analysis, a trained analyst scanned $1 \mathrm{~h}$ LTSAs that were created using a $5 \mathrm{~s}$ time average and $10 \mathrm{~Hz}$ frequency resolution and displayed from 0 to $5 \mathrm{kHz}$. Signals of interest were viewed in a 30 s spectrogram (1000 point FFT length, $65 \%$ overlap) displayed from 0 to $2 \mathrm{kHz}$ to confirm the source of the call. For automatic detection, a detector based on a generalized power law was used, which has a false detection rate under 5\% (Helble et al. 2012). This detector can detect the wide range of humpback whale vocalizations (including both song and non-song call types) across different regions and noise conditions while keeping missed and false detection rates below 5\% (Helble et al. 2012, Rekdahl et al. 2017, Henderson et al. 2018, Zeh et al. 2020). All automatic detections were subsequently verified by a trained analyst using spectrograms that ranged $0.35-3 \mathrm{~s}$ in duration and $0-2000 \mathrm{~Hz}$ in frequency (spectrogram windows were modified when necessary for call verification), and any false detections were removed. There was no effort to classify song and non-song calls with either method. Calls were grouped into encounters, where each encounter was separated by at least $30 \mathrm{~min}$ of recording that did not contain any calls of interest. For deployments with duty-cycled recordings, if the duty-cycle off period was less than $30 \mathrm{~min}$, and calls continued after the recording gap, then the encounter was determined to span the gap. A lack of calls after the recording gap, or a 30 min dutycycle off period, meant the encounter would end with the last call before the recording gap, as there was no way to determine if calls continued during these times. Although detection methods varied at Shelf (Table S1), this same encounter metric was used to report both manual and automatic detections of humpback whales, and the total minutes of encounters were summed each day and averaged over weekly and monthly bins.

Minke whale boings were detected using the same generalized power-law detector used for humpback whale calls (Helble et al. 2012) but were verified using spectrograms that ranged $1-6 \mathrm{~s}$ in duration and $800-1800 \mathrm{~Hz}$ in frequency. This detection method allowed for the manually validated detection of individual minke whale boings that were summed for each day and averaged over weekly and monthly bins.

All remaining call types were analyzed using full bandwidth recordings and are reported as encounters, where the methods for delineating encounters were the same as described previously for humpback whale calls. Hourly LTSAs, created using a $5 \mathrm{~s}$ time average and $100 \mathrm{~Hz}$ frequency resolution, were manually scanned from 0 to $100 \mathrm{kHz}$ for the presence of sperm whale, Risso's dolphin, and Pacific white-sided dolphin clicks. When clicks were identified in an LTSA, a $5 \mathrm{~s}$ spectrogram (1000 point FFT length, $0 \%$ overlap) was examined, if necessary, to confirm click type presence. 
Cuvier's and Stejneger's beaked whale FM pulses, as well as the BW37V signal type (presumed to be produced by Hubbs' beaked whale, Griffiths et al. 2018), were detected automatically by running a Teager-Kaiser energy detector to identify all echolocation signals (Soldevilla et al. 2008, Roch et al. 2011) and then using an expert system to discriminate between delphinid clicks and beaked whale FM pulses (Roch et al. 2011, Baumann-Pickering et al. 2013a). Discrimination was based on detections within a 75 s segment and only segments with more than seven detections were used in further analysis. Echolocation signals were removed if they had a peak and center frequency below 32 and $25 \mathrm{kHz}$, respectively, a duration less than $355 \mu$ s, and a sweep rate of less than $23 \mathrm{kHz} \mathrm{ms}^{-1}$. If more than $13 \%$ of all initially detected echolocation signals remained after applying these criteria, the segment was classified to have beaked whale FM pulses. This threshold was chosen to obtain the best balance between missed and false detections. The automatically detected segments were then analyzed by a trained analyst to remove false detections and label as species-specific pulse types (Baumann-Pickering et al. 2013a). The rate of missed detections was approximately 5\% (Baumann-Pickering et al. 2013a, 2014). There was no detection effort at Shelf or Slope, as Shelf was too shallow for the typical habitat of these beaked whale species and the sampling frequency was too low for four out of the five deployments at Slope (Table S1).

\section{Propagation modeling}

Detection areas should be taken into account when comparing detections of low-frequency baleen whale calls across recording sites (Helble et al. 2013). We used the methodology described by Širović et al. (2015) to determine the detection areas for the three sites in our study, but with adjusted parameters for our study area and call types. To summarize, transmission loss (TL) was modeled using the Effects of Sound on the Marine Environment (ESME) 2012 Workbench framework (D. Mountain, Boston University, http://esme.bu.edu) and sound propagation was modeled using a Range-dependent Acoustic Model (RAM) simulator (Šrović et al. 2015) for all call types except minke whale boings, a call at a higher frequency, for which it was more appropriate to use a BELLHOP model (Porter 2011, Wang et al. 2014).

We ran propagation models for four different frequencies $(20,45,350$, and $1500 \mathrm{~Hz})$ that corresponded to the frequencies of dominant portions of different baleen whale call types (Table S4). Models were calculated along 16 radials that were centered at each recording location and were $200 \mathrm{~km}$ long for blue and fin whale frequencies, $100 \mathrm{~km}$ long for humpback whale calls, and $50 \mathrm{~km}$ long for minke whale boings. Parameters needed for range estimation were specific to each call type (Table S4). We used average background sound levels from August for each site (ambient sound levels had $<5 \mathrm{~dB}$ variation throughout the year) and assumed a $2 \mathrm{~dB}$ signal-to-noise ratio detectability level for each call type (Širović et al. 2015).

Detection areas (Table S5) were then used to normalize the reported fin whale $20 \mathrm{~Hz}$ call and minke whale boing detections by dividing call metrics by the calculated detection area in $1000 \mathrm{~km}^{2}$. Although cross-site comparisons would be improved by detection area normalization for all low-frequency call types, all other call types were reported as hourly presence or total minutes of calling, and it was not meaningful to normalize these detections. However, detection areas were still reported for all low-frequency call types for comparison within this study and with other passive acoustic studies.

\section{Data analyses}

To compare variation in seasonal presence, the relative daily acoustic presence of a given species was calculated for the site where the overall detections of that species were generally the highest. This analysis was based on the total number of days with detections for a given call type, to facilitate reporting of detections using different metrics. For fin whale $20 \mathrm{~Hz}$ calls that were automatically detected, we set a threshold to determine the number of days with acoustic presence, as the fin whale acoustic index does not intrinsically provide binary presence/absence data (even if $20 \mathrm{~Hz}$ calls are absent, the signal-to-noise ratio for the bands used is typically $>0$ ). Therefore, only days with an acoustic index of one or greater (maximum index values typically range from 15 to 20) were counted towards the total number of days with fin whale $20 \mathrm{~Hz}$ call presence. Relative daily presence was calculated for an individual species or call type as the percent of days with acoustic presence during each season from one full year of data. Because recording effort varied at each site, data from the following time periods were used for each site 1 May 2007-30 April 2008 at Slope, 1 February 2011-30 September 2011 and 1 October 2012-1 January 2013 at Canyon. Seasons were defined as winter: December-February, spring: March-May, summer: June-August, fall: September-November. The resulting relative daily presence of species did not account for the different detection ranges across sites and call types.

To further examine spatial and temporal patterns, call detection metrics were grouped into weekly bins to examine seasonal patterns, and into monthly bins to examine interannual patterns at each site. For detections reported in hourly bins, presence was reported as average daily hours per week or per month, for seasonal and interannual plots, respectively. For detections reported as encounters, presence was reported as the average daily 
minutes of detections, again, per week or per month. For minke whale boing detections, the total number of calls was normalized by the detection area for each site (Table S5), resulting in average daily detections per week (or per month) per $1000 \mathrm{~km}^{2}$ for seasonal (or interannual) plots. For the fin whale acoustic index, normalization accounted for transmission loss (TL) as well as detection area (Table S5), as described by Širović et al. (2015). Therefore, the fin whale acoustic index is reported as the average daily index per week (or per month) per $1000 \mathrm{~km}^{2} / \mathrm{TL}$ for seasonal (or interannual) plots. Diel plots (detections versus time of day) were also created to examine any changes in calling between day and night for each call type, except for the fin whale acoustic index.

Since recording effort varied across years and among sites, the average weekly detections reported in the seasonal plots were normalized by recording effort. Figure 2 shows the total number of years with effort for each week at each site. For interannual plots, the effort is noted on a second $y$-axis (right-hand side) to show the percent of effort for a given month. Generalized additive models (GAMs) were also used to examine the seasonal and interannual variation of daily detections for each species at each site. Models were created with a Tweedie distribution and a log link function using the mgcv package (Wood 2011) in R (R Core Team 2020). The response variable in each model was the total number of hours with call presence or total minutes of detections (dependent on species) per day. Predictor variables for the model were Julian day and year. Julian day was modeled with a smooth function that was estimated by a cyclic cubic regression spline with up to four degrees of freedom and year was modeled as a factor. Models were not developed for minke whale boings, as they were only detected on two days. Additionally, models did not account for autocorrelation in the predictor variable. Call totals on adjacent days are likely not independent from one another, particularly for baleen whale species (Širović et al. 2004). Because we were not examining the effect of environmental variables in our models and were only investigating the relationship between Julian day and year, we did not feel that increasing our bin size was warranted. By not accounting for autocorrelation in our models, we may have fit a more complicated model than is justified and our confidence intervals may be underestimated. However, because the models were restricted to four degrees of freedom, the seasonal models are quite simple. Although this restriction may prevent models from successfully capturing finer-scale seasonal patterns for some species, overall, the models show that only some sites had interannual variability, and seasonal patterns were generally consistent across sites.

\section{Results}

Detections were higher at sites farther offshore for all species, and seasonal changes in calling were observed for all species that were commonly detected (Fig. 3). Blue whale B calls, fin whale $20 \mathrm{~Hz}$ calls, and humpback whale calls were more prevalent during the fall and winter, while blue whale D calls were more prevalent during the spring and fall (Fig. 3). Detections of sperm whales, Risso's dolphins, and Pacific white-sided dolphins were highest during the summer, while beaked whale detections were highest during the winter or spring, depending on species (Fig. 3). Spatial and temporal patterns in calling are described in more detail below for each species.

\section{Blue and fin whales}

Blue whale calls were detected at all three sites, with B calls more prevalent than D calls overall. B call detections were highest at Slope and lowest at Canyon, and were highest during the fall and winter at all sites (Fig. 4, Table S6). D call manual detections had an inconsistent seasonal pattern: at Shelf there was a significant peak in manual detections in late summer and fall, Slope had intermittent peaks throughout the year, and at Canyon, calls were significantly higher in winter and early spring (Fig. 4, Table S6). However, at all sites, D call manual detections were low during the spring and early summer (Fig. 4). There was no clear diel pattern for either blue whale call type. There was some interannual variation in the number of detections: at Shelf, B call detections were high during 2006, 2007, and 2008, but decreased in 2009, at Slope, calls were high during 2006 and 2007, at Canyon, they were high in 2013 (Figs. 4b and 5, Table S6). For D calls, manual detections were high in 2009 at Shelf and in 2013 at Canyon (Figs. $4 \mathrm{~b}$ and 5, Table S6).

The fin whale acoustic index was highest at Canyon and showed a seasonal peak in the fall and winter at all sites (Fig. 4, Table S6). Since the energy detector used for $20 \mathrm{~Hz}$ calls provides an average daily index of calling, we were unable to examine diel patterns for this call type. There was no clear interannual trend in the $20 \mathrm{~Hz}$ index, but the average daily fin whale acoustic index appeared high at Shelf in 2011, although this was not significant in the GAM (Fig. 5, Table S6). Instead, the models showed that the acoustic index was significantly lower during 2006 at Shelf, but higher during 2007 and 2008 at Shelf and Slope, as well as during 2012 at Shelf and Canyon, and still during 2013 at Canyon (Fig. 4b, Table S6).

\section{Humpback and minke whales}

Humpback whale detections were highest at Canyon and lowest at Slope, although calls increased during the fall and winter at all three sites (Fig. 6a). At Shelf, detections began 


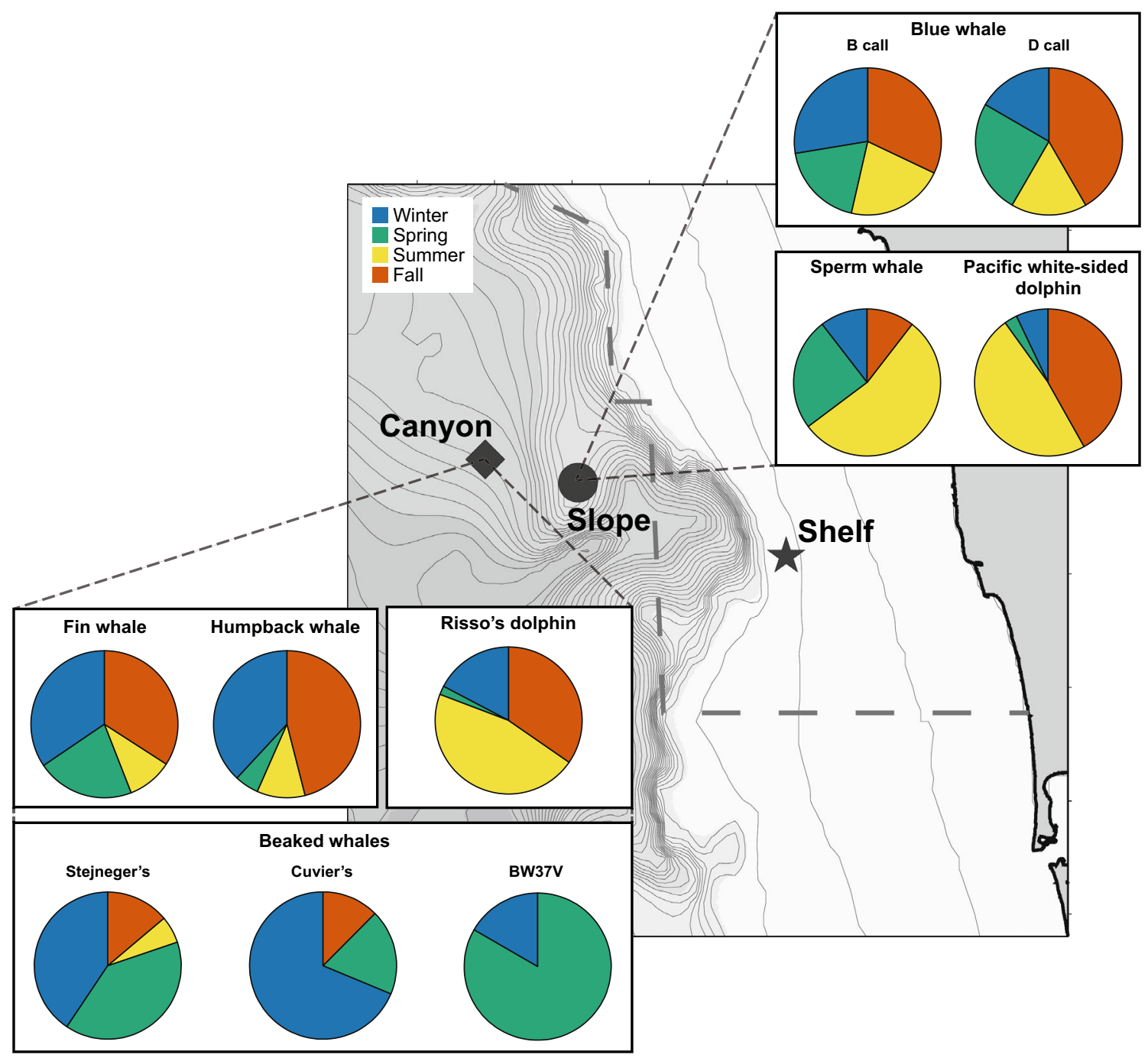

Fig. 3 Relative seasonal presence of select species during each season from one year of data (see Data analyses in Methods for exact time periods used) at two sites offshore of Washington. Species are shown for the site at which presence was highest: blue whale call types, as well as sperm whale and Pacific white-sided dolphin clicks, are shown for Slope, while fin whale, humpback whale, Risso's dolphin, and beaked whale calls are shown for Canyon. No species had the highest overall presence at the Shelf site increasing during the summer and were highest during the fall and winter, with a drop in November (Fig. 6a). At Slope, detections occurred from September to December and were rare the rest of the year (Fig. 6a). At Canyon, detections were rare during spring and summer but were high throughout the fall and winter (Fig. 6a). The models captured these slight variations in the seasonal presence of humpback whale calls at each site because, while all sites show a significant peak in detections during the fall and winter, the peak at Shelf occurs earliest in the year and the peak at Canyon occurs latest (Fig. 6b, Table S6). There was no clear diel pattern to humpback whale detections. Interannually, detections increased during 2011 at Shelf (Fig. 5) and the model showed that detections were significantly higher in 2011, as well as during 2012 and 2013 (Fig. 6b, Table S6). At slope, the model showed that calls were low during 2004 (Fig. 6b, Table S6).

Minke whale boings were detected only at Canyon (Fig. 6a). There was one manually validated detection on April 26, 2013. Other manually validated detections (324) occurred on November 15, 2012 within a $3 \mathrm{~h}$ period ( $\sim 300-0600 \mathrm{~h}$ ). Since calls mainly occurred on one day, further examination of diel, seasonal, or interannual trends for this species was not possible.

\section{Sperm whales, Risso's dolphins, and Pacific white-sided dolphins}

Sperm whale clicks were manually detected year-round at all three sites but were highest at Slope (Fig. 7a). At 
(a)

(b)
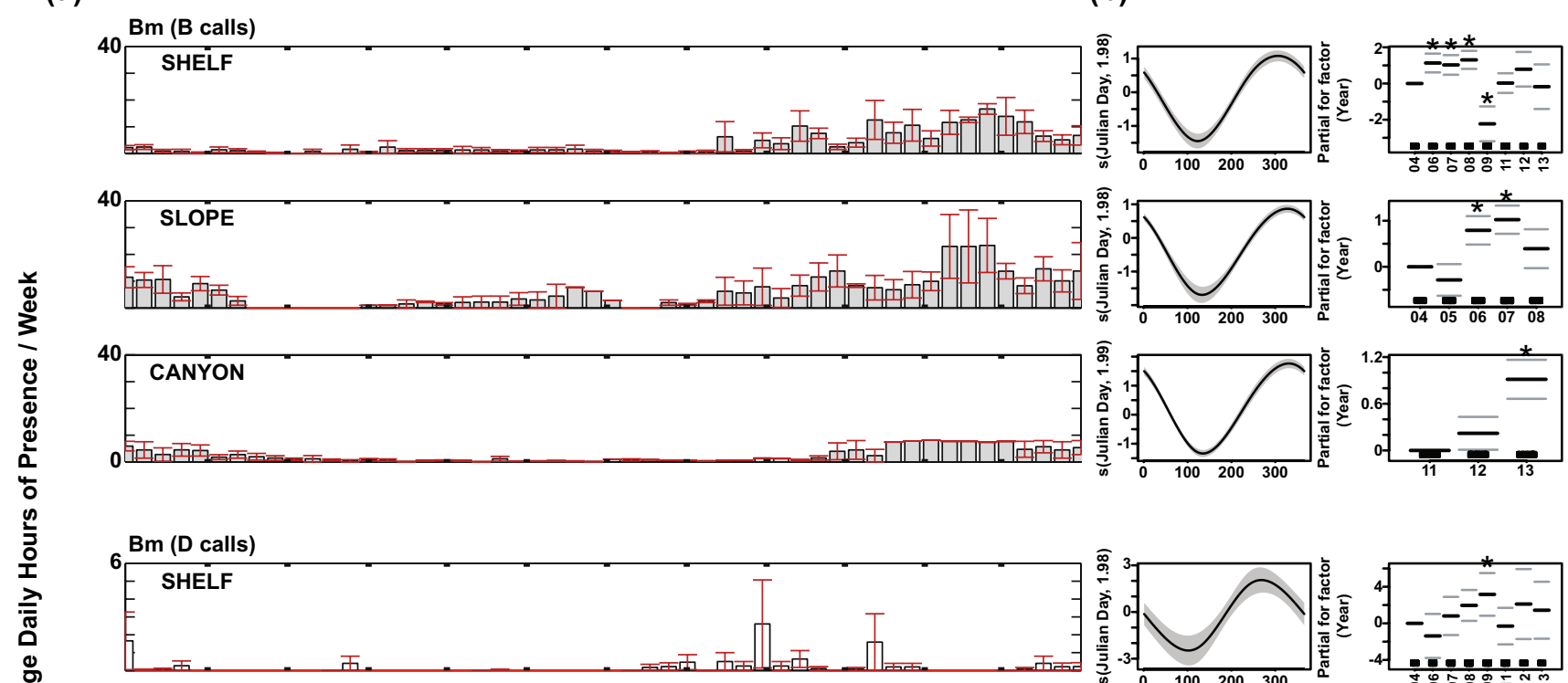

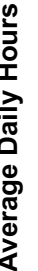
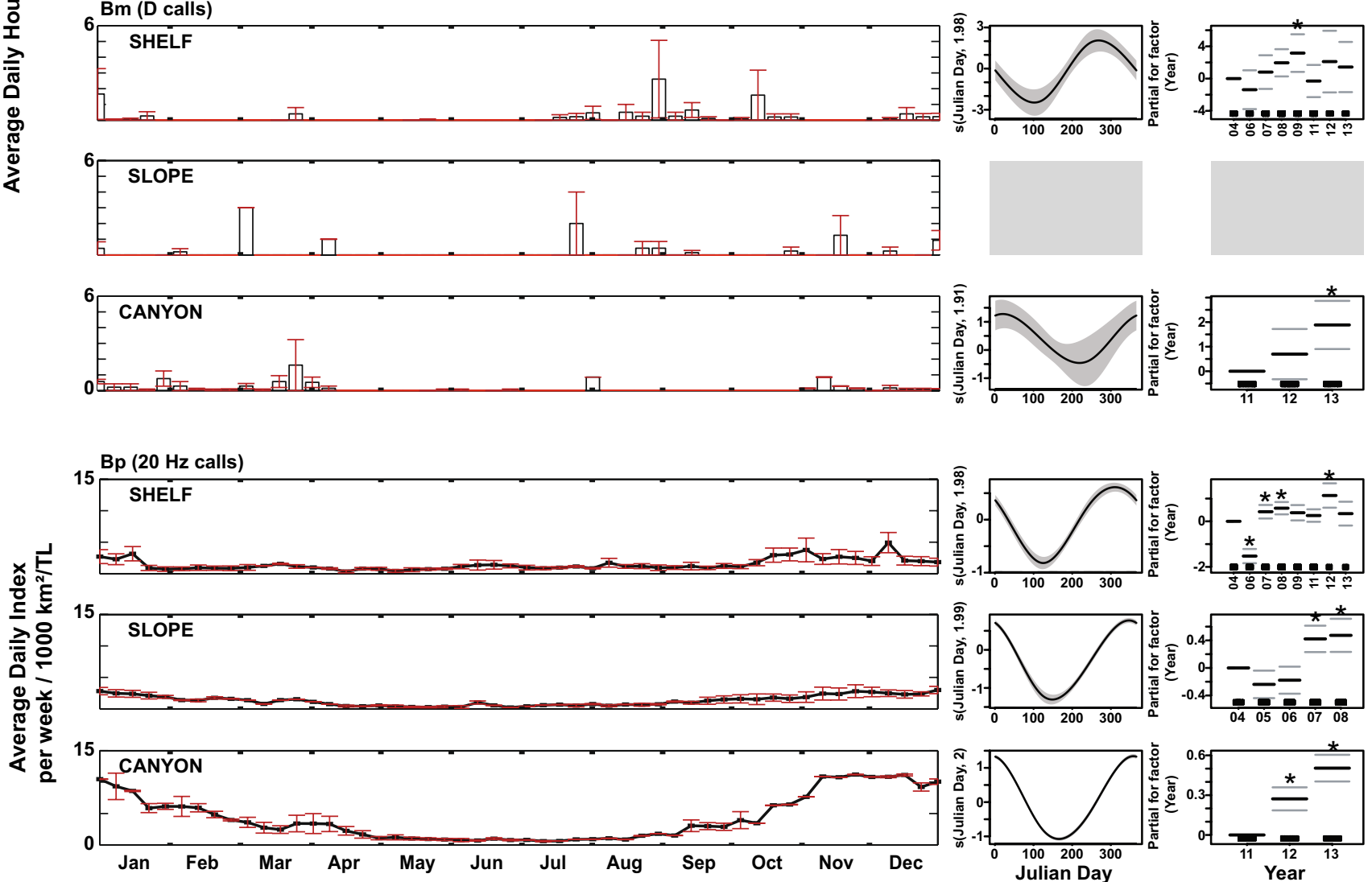

Fig. 4 a Mean weekly presence of blue whale $(\mathrm{Bm}) \mathrm{B}$ calls (light gray bars), D calls (white bars), and fin whale (Bp) acoustic index (black line) at three locations offshore of Washington. Data were averaged across years with recording effort from 2004 to 2013, red error bars represent standard error. The number of years with recording effort for each week is shown in Fig. 2. b Corresponding generalized additive models (GAMs) with significant $(p<0.01)$ results for blue and fin whale call types at each site. Total daily hours of call

both Shelf and Slope, manual detections peaked from late spring to early summer (Fig. 7, Table S6), while at Canyon, occasional peaks occurred throughout the year (Fig. 7a). There was no diel pattern for sperm whale clicks. presence (the daily fin whale $20 \mathrm{~Hz}$ acoustic index value for automatically detected $20 \mathrm{~Hz}$ calls) are modeled as a function of Julian day (left) and year (right). The shaded band (left) and horizontal bars (right) represent two standard error bounds. Asterisks represent years that are significantly different from the first year (see Table S6 for $p$ values). $Y$-axis scales vary to show model fit. Gray boxes indicate GAMs that were not statistically significant

Also, there was no clear interannual pattern in manual detections, although the number of clicks did appear to fluctuate over the years of the study: manual detections were low during 2006, 2007, and 2008 at Slope, during 
Fig. 5 Monthly presence of blue whale $(\mathrm{Bm}) \mathrm{B}$ calls (upper light gray bars) and D calls (upper white bars), fin whale $20 \mathrm{~Hz}$ acoustic index (Bp, black line), humpback whale calls (Mn, lower light gray bars), and minke whale boings ( $\mathrm{Ba}$, lower white bars) from 2004 to 2013 at three locations offshore of Washington. Gray dots denote months with $<100 \%$ recording effort, gray shading denotes periods with no recording effort, and diagonal hatching denotes periods with duty-cycled recording. There were no minke whale detections at Shelf or Slope
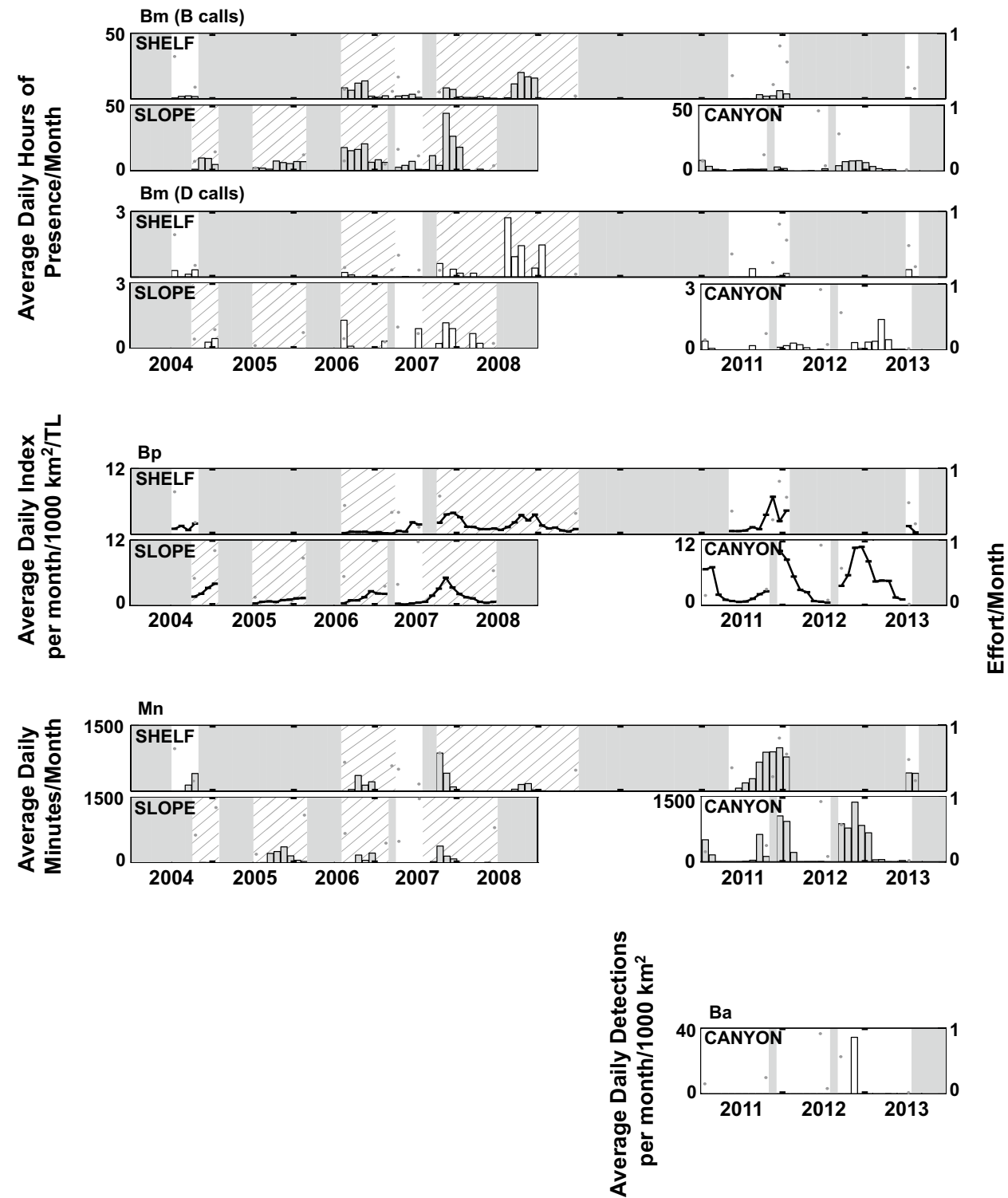

2009 at Shelf, and during 2012 at Canyon (Figs. 7b and 8, Table S6).

Risso's dolphin clicks were manually detected at all three sites and were highest at Canyon (Fig. 7a). Clicks were most common during the summer and early fall at all sites, although this seasonal pattern was most prominent at Canyon (Fig. 7, Table S6). Risso's dolphin clicks occurred almost exclusively at night, particularly at Canyon (Fig. 9). There was no clear interannual pattern in Risso's dolphin clicks, but the models indicated a decrease in detections during 2008 at Slope and an increase at Canyon during 2012 and 2013 (Figs. 7b and 8, Table S6).

Pacific white-sided dolphin manual detections were highest at Slope and lowest at Shelf. Clicks occurred seasonally, from summer to early winter, at all three sites (Fig. 7a). This seasonal pattern was only significant at Slope and Canyon (Fig. 7b, Table S6). Pacific white-sided dolphin clicks occurred more often at night, particularly at Slope and Canyon (Fig. 9). There was no clear interannual pattern in Pacific white-sided dolphin click manual detections: at Shelf, clicks were low from 2006 to 2008, at Slope, clicks were also low during 2006 and 2008, at Canyon, clicks were low during 2013 (Figs. 7b and 8, Table S6).

\section{Beaked whales}

While Stejneger's, Cuvier's, and presumable Hubbs' (BW37V) beaked whale clicks all occurred at Canyon, Stejneger's beaked whale clicks were detected most frequently (Fig. 10a). Manually validated detections of Stejneger's and Cuvier's beaked whale clicks showed similar seasonal patterns: few clicks from July to September, an increase during fall and winter, and a decrease throughout the spring (Fig. 10). Likely Hubbs' beaked whale (BW37V) clicks 
(a)

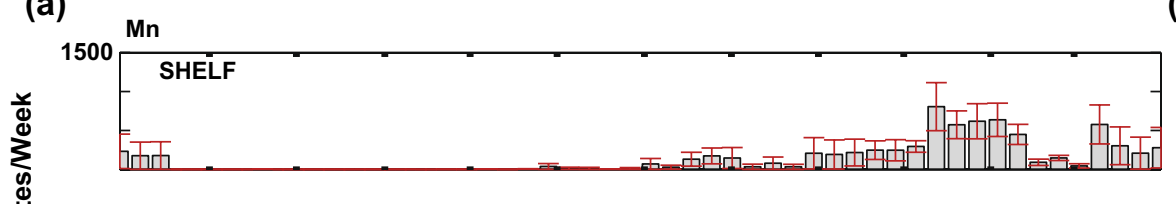

1500 SLOPE

过

을

1500

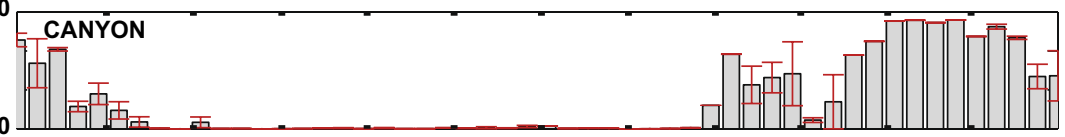

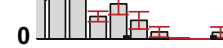

$\mathrm{Ba}$ (b)
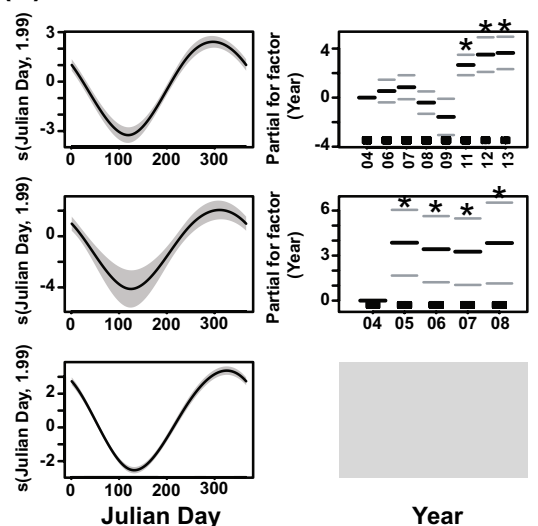

Year
Fig. 6 a Mean weekly presence of humpback whale calls (Mn, light gray bars) and minke whale boings ( $\mathrm{Ba}$, white bars) at three locations offshore of Washington. Data were averaged across years with recording effort from 2004 to 2013, red error bars represent standard error. The number of years with recording effort for each week is shown in Fig. 2. There were no detections of minke whale boings at Shelf or Slope. b Corresponding generalized additive models (GAMs) with significant $(p<0.01)$ results for humpback whale calls at each site.

were detected in winter, starting in December, but occurred primarily during the spring (Fig. 10a). There was no discernable diel or interannual pattern for any beaked whale species (Fig. 8).

\section{Discussion}

Cetacean detections were generally more common at the two sites farther offshore (sites Slope and Canyon), and only blue and humpback whales had a substantial number of detections on the continental shelf (site Shelf). The continental slope (site Slope) showed the most blue whale B calls, as well as the highest levels of clicks from sperm whales and Pacific white-sided dolphins, while detections of fin, humpback, and minke whales, and Risso's dolphins were highest around the submarine canyon (site Canyon). In addition to these spatial patterns, we observed seasonal changes in calling for all species except minke whales, for which calls did not occur frequently enough to establish temporal patterns. These seasonal patterns were most consistent across sites for blue whale B calls, the fin whale $20 \mathrm{~Hz}$ acoustic index, and humpback whale calls. We also found increased nighttime calling in Risso's and Pacific white-sided dolphins. In
Total daily minutes of call presence is modeled as a function of Julian day (left) and year (right). The shaded band (left) and horizontal bars (right) represent two standard error bounds. Asterisks represent years that are significantly different from the first year (see Table S6 for $p$ values). $Y$ axis scales vary to show model fit. Gray box indicates GAM that was not statistically significant. GAMs were not run for minke whales due to detections occurring on only two days

general, many of these spatial and temporal patterns have been observed previously (Green et al. 1992, Watkins et al. 2000, Barlow and Forney 2007, Oleson et al. 2009, Soldevilla et al. 2010b) and therefore support earlier findings about the distributions of these species offshore of Washington and demonstrate the stability of these patterns over long time periods. Additionally, the high degree of calling found at offshore locations highlights the importance of conducting cetacean surveys in deep pelagic habitats that are clearly of great significance to these species.

When interpreting results from passive acoustic studies, it is important to acknowledge that the methodology is inherently biased towards animals that are vocalizing. A lack of acoustic detections does not mean that animals were not present in the area; they could have been engaged in non-vocal behaviors or producing calls that were not used for species identification in this study. It is also possible the inclusion of duty-cycled data resulted in an underestimate of acoustic presence during the early years of the study; therefore, it is necessary to consider methodological differences when comparing acoustic presence across years. Additionally, although we are confident that we recorded Stejneger's beaked whales in our recordings (Baumann-Pickering et al. 2013b), there have been 
(a)
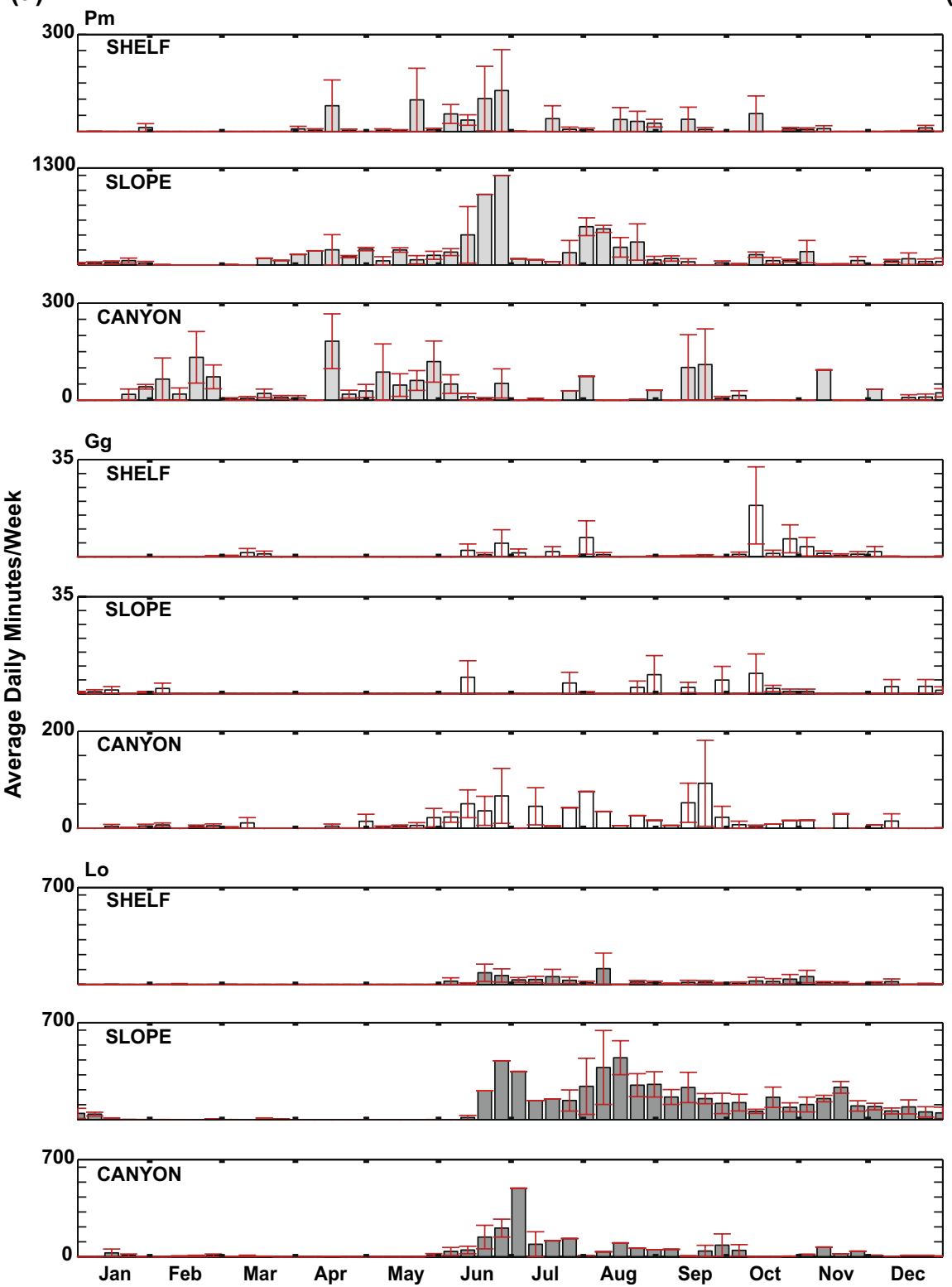

(b)
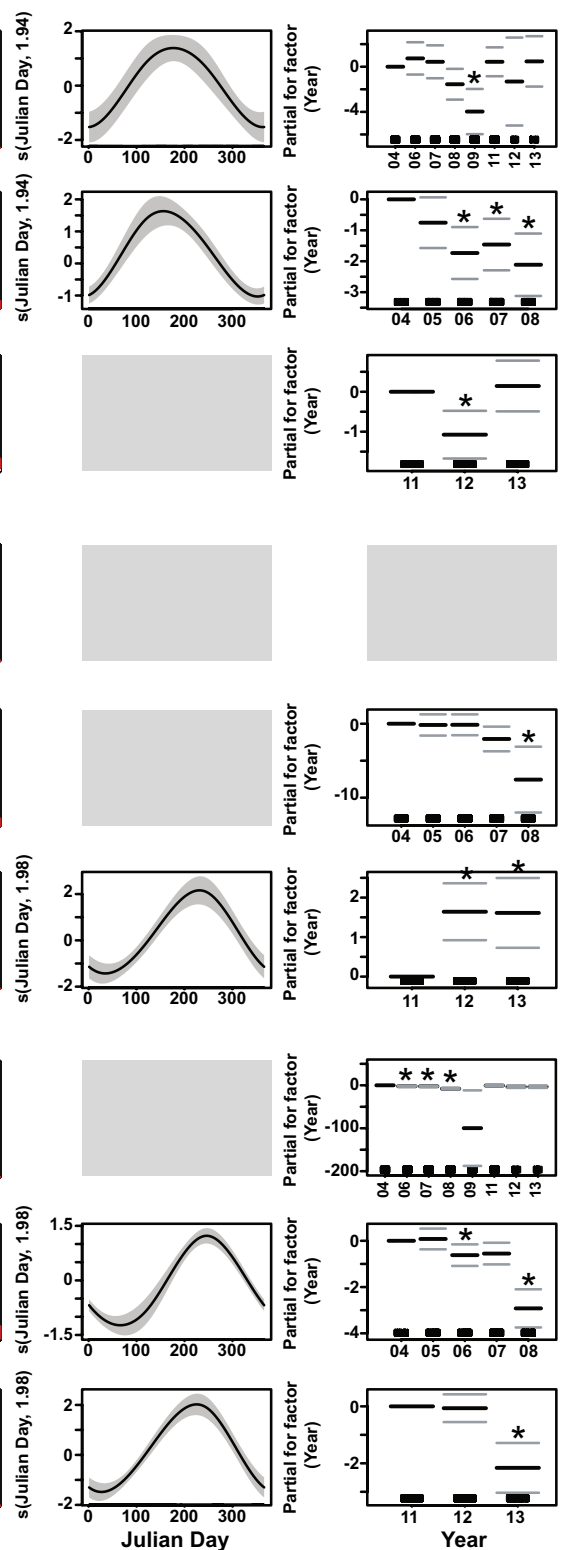

Fig. 7 a Mean weekly presence of sperm whale (Pm, light gray bars), Risso's dolphin (Gg, white bars), and Pacific white-sided dolphin (Lo, dark gray bars) clicks at three locations offshore of Washington. Data were averaged across years with recording effort from 2004 to 2013, red error bars represent standard error. The number of years with recording effort for each week is shown in Fig. 2. Note different $y$ axis scale was used between sites for sperm whale and Risso's dolphin clicks. b Corresponding generalized additive models (GAMs)

no acoustic detections of Stejneger's beaked whales with concurrent visual confirmation. This is also true for the BW37V click type, which is hypothesized to be produced by Hubbs' beaked whale (Griffiths et al. 2018), but for which there have been no concurrent visual confirmations to date. Therefore, our results for these species should be interpreted with caution. with significant $(p<0.01)$ results for the sperm whale, Risso's dolphin, and Pacific white-sided dolphin clicks at each site. Total daily minutes of call presence are modeled as a function of Julian day (left) and year (right). The shaded band (left) and horizontal bars (right) represent two standard error bounds. Asterisks represent years that are significantly different from the first year (see Table S6 for $p$ values). $Y$-axis scales vary to show model fit. Gray boxes indicate GAMs that were not statistically significant

\section{Blue and fin whales}

Sightings of blue whales offshore of Washington, although relatively rare, typically occur along the continental slope (Calambokidis and Barlow 2004, Barlow and Forney 2007, Bailey et al. 2009), while fin whale sightings are most common at or beyond the shelf break (Green et al. 1992, Oleson 
Fig. 8 Monthly presence of sperm whale (Pm, upper light gray bars), Risso's dolphin (Gg, upper white bars), Pacific white-sided dolphin (Lo, gray bars), Stejneger's beaked whale (Ms, lower light gray bars), Cuvier's beaked whale (Zc, lower white bars), and possible Hubbs' beaked whale signal type BW37V (lower gray bars) clicks from 2004 to 2013 at three locations offshore of Washington. Gray dots denote months with $<100 \%$ recording effort, gray shading denotes periods with no recording effort, and diagonal hatching denotes periods with duty-cycled recording. Note different $y$ axis scale was used between sites for sperm whale and Risso's dolphin clicks

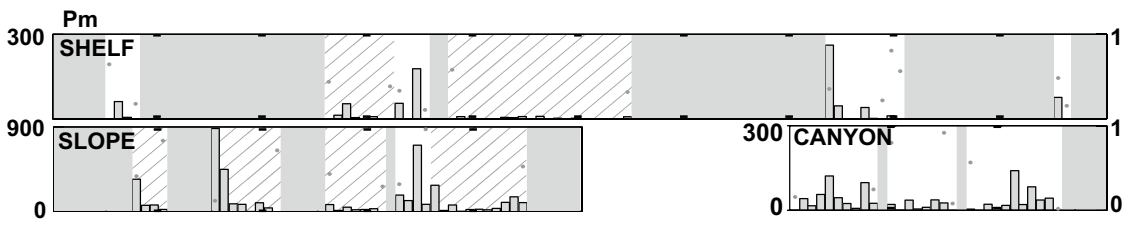

$\mathrm{Gg}$

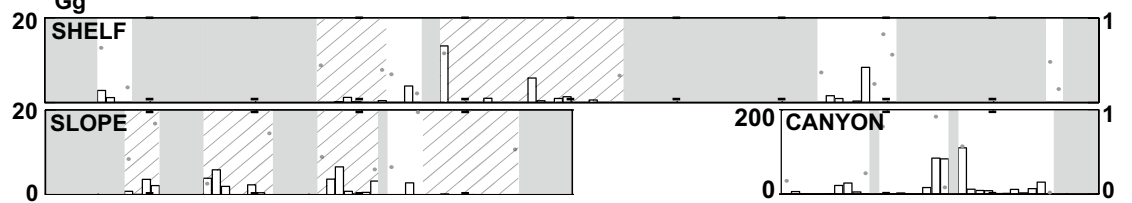

Lo

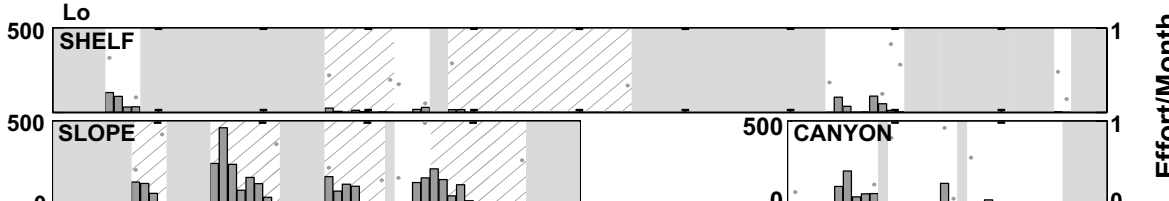

Ms

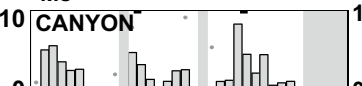

Zc

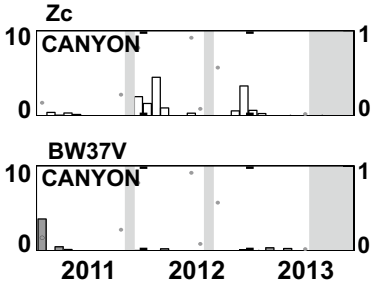

et al. 2009, Schorr et al. 2010). Similarly, we found that blue whale call detections were highest at Slope and Shelf, while the fin whale acoustic index was highest at Canyon (Fig. 4). Submarine canyons are often areas of higher krill abundance (Santora et al. 2018) and may provide foraging opportunities for fin whales (Burnham et al. 2021), possibly explaining evidence of increased fin whale presence around these bathymetric features (Schorr et al. 2010, Aulich et al. 2019).

Blue whale $\mathrm{B}$ calls and the fin whale acoustic index were highest during the fall and winter (Fig. 4), as has been observed previously offshore of Washington (Moore et al. 1998, Watkins et al. 2000, Stafford et al. 2001, Soule and Wilcock 2013, Koot 2015, Weirathmueller et al. 2017), and in other areas of the eastern North Pacific (Watkins et al. 2000, Barlow and Forney 2007, Oleson et al. 2007b, 2014, Širović et al. 2013, 2015, Rice et al. 2021). Both call types are widely assumed to be associated with reproductive behavior (Watkins 1981, Watkins et al. 1987, McDonald et al. 2001, Croll et al. 2002, Oleson et al. 2007a, 2007b, Lewis et al. 2018), while blue whale D calls, which we manually detected much more sporadically (Fig. 4), are generally associated with other social behaviors and foraging (McDonald et al. 2001, Oleson et al. 2007a, 2007b, Lewis et al. 2018). In other regions, it is typical for $D$ calls to show a seasonal increase, often during spring and summer (Oleson et al. 2007b, Rice et al. 2021), when blue whales are feeding in more productive high-latitude waters. The waters offshore of Washington are not considered a primary feeding area for blue whales (Calambokidis et al. 2015), thus the lack of D calls we manually detected during summer may be explained by limited blue whale presence during this season. Instead, blue whales may feed in areas to the south, offshore of California (Oleson et al. 2007b, Calambokidis et al. 2015), and farther north, in the Gulf of Alaska, where D calls were manually detected throughout the spring and summer (Rice et al. 2021). The majority of the D calls in this study occurred either in the early spring or late summer, at the margins of the seasonal increase in B calls (Fig. 4), supporting the suggestion that blue whales are primarily seasonal visitors to the region.

Since blue and fin whales both consume krill offshore of Washington (Flinn et al. 2002), the lack of fin whale calls during summer might be taken to indicate movement out of the region to forage in a different area as well. However, we did not monitor for the presence of $40 \mathrm{~Hz}$ calls in this study, which may be more common during foraging (Watkins 1981, Širović et al. 2013) and were the primary fin whale call type recorded during spring off Vancouver Island, British Columbia (Burnham et al. 2021). In other North Pacific regions, fin whale year-round presence has been documented by the detection of both $20 \mathrm{~Hz}$ and $40 \mathrm{~Hz}$ calls (Širović et al. 2013, Rice et al. 2021). Therefore, because we did not attempt to 
Fig. 9 Diel presence (blue horizontal lines) of Pacific white-sided dolphin (Lo) and Risso's dolphin (Gg) clicks in one-minute bins from 2004 to 2008 at Slope and from 2011 to 2013 at Canyon. Gray hourglass shading denotes nighttime and light blue horizontal shading denotes periods with no recording effort

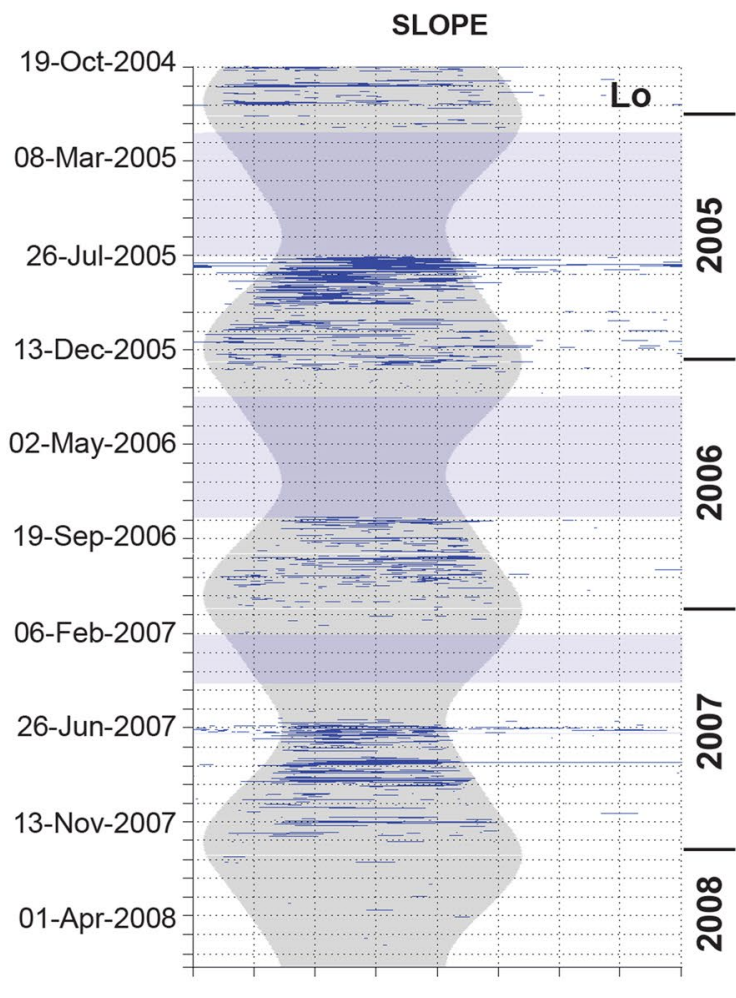

CANYON

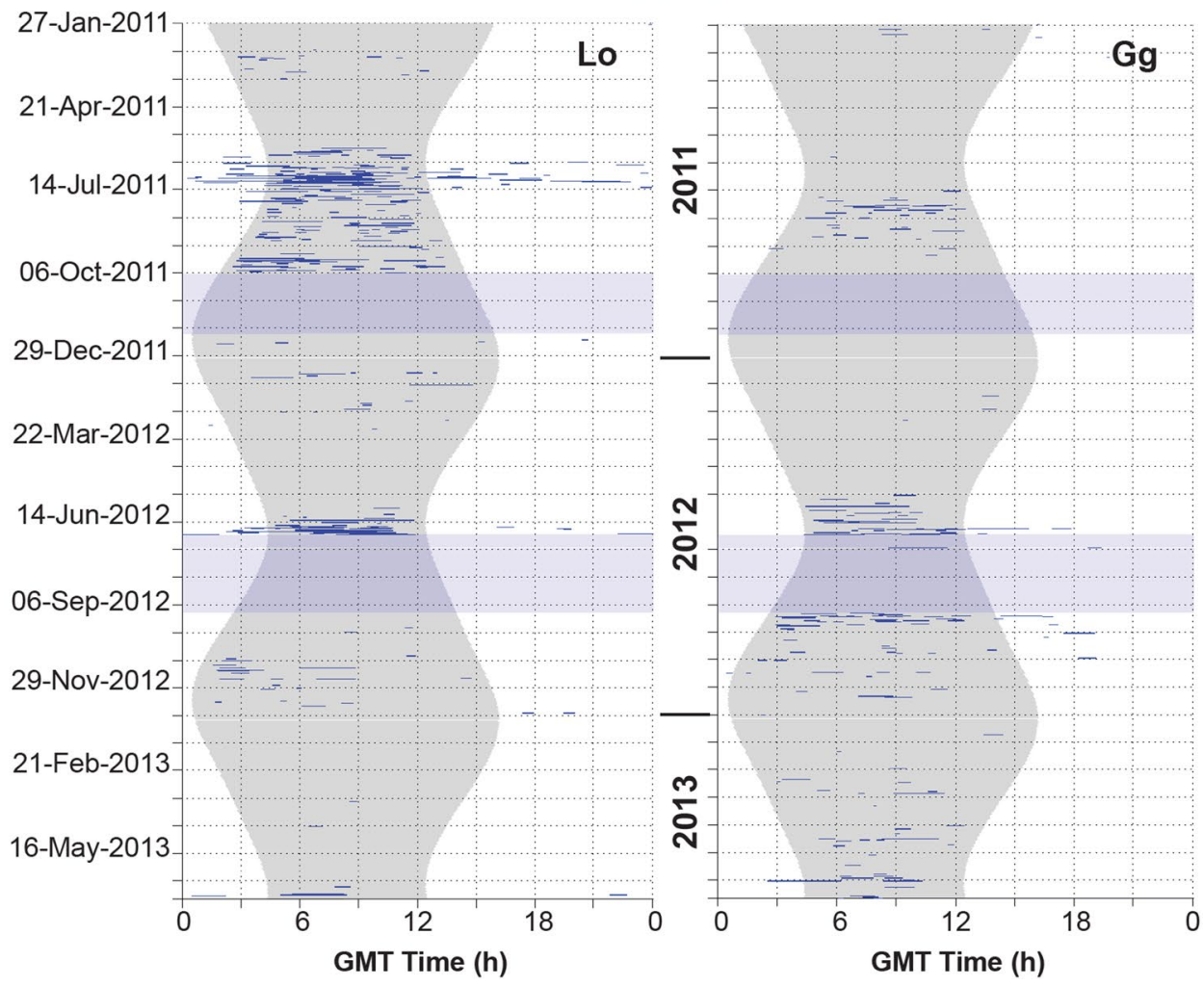

detect $40 \mathrm{~Hz}$ calls in this data, and because visual surveys and historic catch data show increased fin whale presence offshore of Washington during the summer (Green et al. 1992, Mizroch et al. 2009), it seems likely that at least some fin whales are utilizing this region year-round, for foraging in the summer and breeding during the winter, even though the acoustic detections reported here only highlight this latter behavior. 


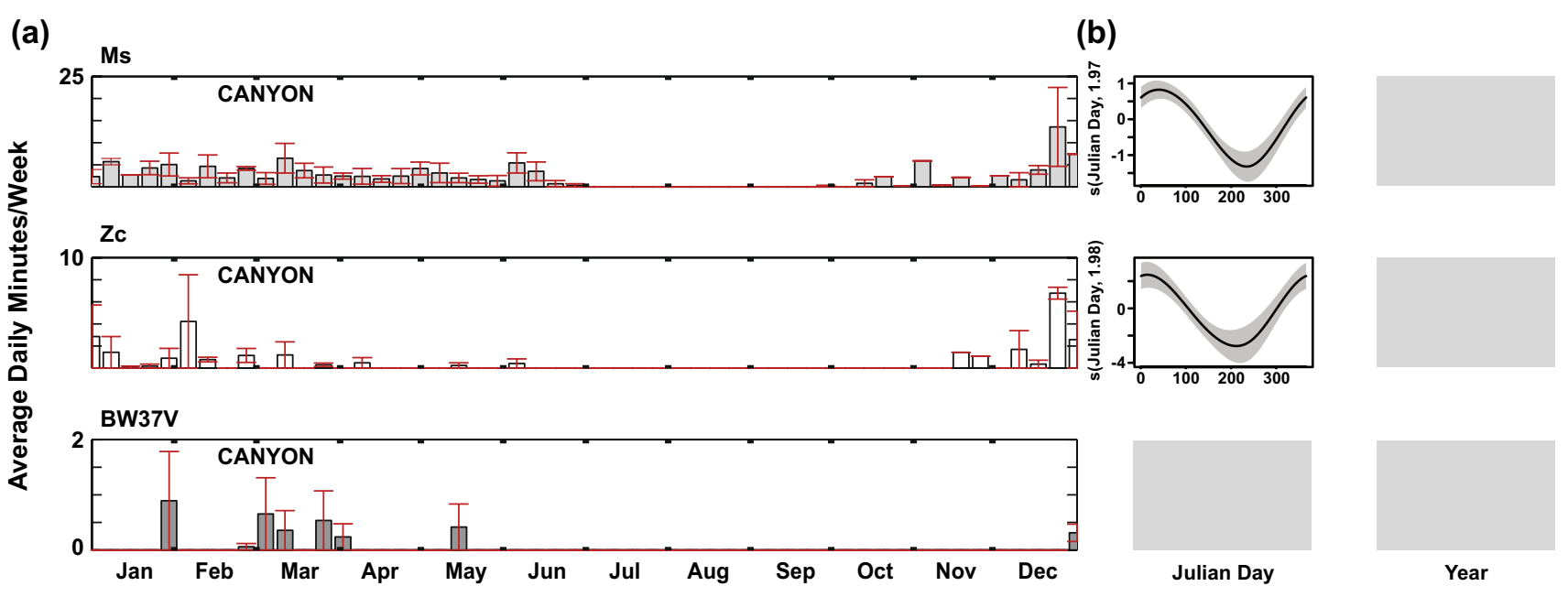

Fig. 10 a Mean weekly presence of Stejneger's (Ms, light gray bars), Cuvier's (Zc, white bars), and likely Hubbs' (BW37V, dark gray bars) beaked whale clicks offshore of Washington. Data were averaged across years with recording effort from 2004 to 2013, red error bars represent standard error. The number of years with recording effort for each week is shown in Fig. 2. b Corresponding generalized addi-

There were noticeable interannual variations for both blue and fin whales, primarily during 2007/2008 and 2011/2012, which correspond with a transition into a cool phase of the Pacific decadal oscillation (PDO) and a switch in the El Niño southern oscillation (ENSO), respectively (Bjorkstedt et al. 2011). At Slope in 2007, the winter peak in blue whale B calls was higher than in previous years, while at Shelf, the highest peak in $\mathrm{D}$ call manual detections occurred in the late summer and fall of 2008 (Fig. 5). While this increase in B calls at Slope during 2007 was significant in our model, the increase of D calls in 2008 was not (Fig. 4b, Table S6). For fin whales, there were also significant increases in the acoustic index during 2007 and 2008 at Shelf and Slope (Fig. 4b, Table S6). Since productivity is typically higher during cool phases, these increases in calls could be a result of increased prey availability (Peterson et al. 2017, Lilly and Ohman 2018). Historical catches of blue whales were higher offshore of British Columbia during cool phases (Calambokidis et al. 2009), supporting a hypothesis that their presence is likely higher in the region during these periods of higher productivity. While this cool phase continued until 2013, there was an abrupt shift from an El Niño in 2010 to a La Niña in 2011 (Bjorkstedt et al. 2011). At Shelf, we observed an increase in fin whale calls during the fall and winter of 2011/2012, compared to previous years (Fig. 5). Again, the increased productivity that follows a return to cooler water temperatures may have led to an increase in the presence or a behavioral shift that resulted in higher calling during this year. Forage fish, which compose part of the fin whale diet offshore of Washington (Flinn et al. 2002), showed increased productivity in 2011 (Peterson et al. 2019), providing a tive models $(\mathrm{GAMs})$ with significant $(\mathrm{p}<0.01)$ results for Stejneger's and Cuvier's beaked whale click seasonality at Canyon. Total daily minutes of call presence are modeled as a function of Julian day. The shaded band represents two standard error bounds. Y axis scales vary to show model fit. Gray boxes indicate GAMs that were not statistically significant

possible explanation for the increase in calls. Offshore of California, marine mammal distributions were also affected by ENSO events, with potential movement out of impacted regions (Keiper et al. 2005). However, for both blue and fin whales, our models show a significant increase in calls during 2013 at Canyon; therefore, it is possible that the presence of these species was increasing in the region during the later years of this study, explaining the apparent increase in 2011 and 2012. It is unclear whether the interannual changes in calling observed offshore of Washington are a direct result of a regional increase in productivity or a more indirect result of distributional shifts spurred by oceanographic conditions in other regions.

\section{Humpback whales}

Humpback whale detections were highest at Canyon and Shelf (Fig. 6), which is generally consistent with visual surveys offshore of Washington, where humpback whales are primarily sighted over the continental shelf (Barlow and Forney 2007, Oleson et al. 2009), sometimes concentrated around canyons (Green et al. 1992). It is unclear why detections would be comparatively lower along the continental slope, although this was also observed in the Gulf of Alaska (Rice et al. 2021). Differences in detection area likely do not explain this spatial pattern, as the detection areas for Slope and Canyon are similar (Table S5).

Humpback whale detections were higher during the later years of the study at Shelf (2011-2013, Fig. 6b), and were also detected over a longer period. Until 2008, calls typically occurred from September through December (Fig. 5). 
Starting in 2011, detections started during the summer and continued through January (Fig. 5). This change coincides with the abrupt ENSO shift that occurred in 2010/2011 (Bjorkstedt et al. 2011). As with fin whales, increased productivity could have resulted in increased or prolonged presence of humpback whales offshore of Washington during these years, explaining the higher number of detections and the longer calling season that we observed. However, abundance estimates and increased sightings in the inner waters of Washington during these years point towards an increasing humpback population in the region (Calambokidis et al. 2017; Calambokidis and Barlow 2020). Therefore, it is possible that these changes may reflect an increasing trend in humpback presence offshore of Washington as opposed to a transitory response to an ENSO shift.

While acoustic detections occurred almost exclusively during winter (Fig. 6), humpback whale sightings are highest offshore of Washington during the summer (Green et al. 1992, Oleson et al. 2009, Calambokidis et al. 2015) when many humpback whales forage in the region (Calambokidis et al. 2015). From these visual observations, we know that the low number of detections during spring and summer is not due to the absence of humpback whales. While there is evidence that humpback whales move inshore (Gregr et al. 2000, Oleson et al. 2009), and out of our detection range, to feed in more coastal waters during the summer (Calambokidis et al. 2015), the primary reason for this seasonal variation in calling is likely related to a shift from foraging behavior during the summer to reproductive behavior during the winter. During the winter breeding season, male humpback whales produce song (Winn and Winn 1978, Tyack 1981, Baker and Herman 1984, Herman et al. 2013, Herman 2017). Because a song consists of long, repetitive series of vocalizations (Payne and McVay 1971, Dunlop et al. 2007), it is possible for detections to be higher even in the presence of fewer animals. Our humpback whale detections are likely biased towards song because non-song calls are often short, quiet calls with a very low fundamental frequency (Stimpert et al. 2011, Wild and Gabriele 2014, Fournet et al. 2015) that may have been missed by our detection algorithm or during manual scanning. The detection area for song is also larger than for non-song calls (Table S5) and the metric we used to describe humpback whale calling (daily minutes of calling) likely highlighted this seasonal difference in acoustic behavior more than a metric such as presence/absence would have. Efficient discrimination of humpback song and non-song calls would require the aid of an automatic classifier, which was beyond the scope of this study. However, we hypothesize that we mostly detected humpback whale song in our data based on the strong seasonal pattern we observed, which matches the seasonal occurrence of song in other regions of the North Pacific (Norris et al. 1999, Au et al. 2000, Watkins et al. 2000, Stafford et al. 2007). If the calls we detected were confirmed as song, it would add to the growing list of high-latitude locations where song has been recorded (McSweeney et al. 1989, Gabriele and Frankel 2002, Clark and Clapham 2004, Stafford et al. 2007, Stimpert et al. 2012, Vu et al. 2012, Garland et al. 2013, Kowarski et al. 2018).

\section{Minke whales}

Offshore of Washington, sightings of minke whales typically occur along the continental shelf (Forney 2007, Oleson et al. 2009) and there is evidence of individuals showing site fidelity to nearshore foraging areas during summer (Hoelzel et al. 1989, Dorsey et al. 1990, Towers et al. 2013). The low number of boings we detected may be due to the presence of minke whales closer to shore, outside of our detection range, or to a reduction in vocalizations to avoid detection by transient killer whales (Orcinus orca), which are a known predator of minke whales (Ford et al. 2005) and were acoustically detected at these same recording locations (Rice et al. 2017). However, as minke whales produce additional vocalizations in this region, it is possible we are not capturing their full occurrence by using just one call type. Offshore of British Columbia, for example, downsweeps and pulse chains were the main call types recorded from minke whales during the summer (Nikolich and Towers 2020).

In the North Pacific, boings have primarily been detected during the winter at low latitudes (Thompson and Friedl 1982, Rankin and Barlow 2005), indicating that minke whales may transition from lower latitude breeding grounds in the winter to higher latitude feeding grounds for the summer, as occurs in the Atlantic (Risch et al. 2014, Vikingsson and Heide-Jorgensen 2015). To date, the only other detections of minke whale boings at higher latitudes occurred during the summer and fall in the Chukchi Sea (Delarue et al. 2013). If minke whales are moving north in the spring and back south in the fall, it is possible that our sparse manually validated detections, which occurred during these transition seasons (Fig. 6), were from individuals undertaking such a migration, either to a region farther north of Washington or to farther inshore waters.

\section{Odontocete spatio-temporal patterns}

Detections were higher at offshore sites for all odontocete species (Figs. 7 and 10), as found in previous studies (Green et al. 1992, 1993, Barlow and Forney 2007, Oleson et al. 2009). However, between the three odontocete families analyzed, there was limited overlap in peak click detections: sperm whales were detected most in the early summer, delphinid species in the summer and fall, and beaked whales in the winter and spring (Figs. 3, 7, and 10). Since we detected echolocation clicks for these species, our detections are 
likely a better proxy of foraging than of overall species presence offshore of Washington. Therefore, these seasonal and spatial trends are potentially related to the presence of prey.

The spatial and temporal patterns of odontocete click detections that we describe highlight the importance of conducting comparable studies over large spatial scales. Studies ranging along the west coast of North America have led to hypotheses about the movements of different populations, and since acoustics are increasingly being used to discriminate between populations, it may be feasible to verify these hypotheses and better inform conservation strategies using these methods.

\section{Sperm whales}

Although sperm whales are known to forage at high latitudes during the summer (Madsen et al. 2002, Whitehead 2003), manually detected clicks were lower during this season offshore of Washington compared to other regions in the North Pacific (Mellinger et al. 2004, Diogou et al. 2019, Rice et al. 2021). This, coupled with the low number of visual sightings from surveys of the region (Green et al. 1992, Barlow and Forney 2007), suggests that the waters offshore of Washington likely do not represent a primary foraging area for sperm whales and the region generally appears to be utilized less by sperm whales than other regions of the eastern North Pacific. Additionally, offshore of British Columbia, there is evidence that male and female sperm whales seasonally vary their prey consumption (Flinn et al. 2002), as well as their distance from shore (Gregr et al. 2000, Flinn et al. 2002). Acoustic analyses of sperm whales may therefore need to account for these demographic differences to accurately reveal spatial and temporal distribution patterns.

\section{Risso's and Pacific white-sided dolphins}

Risso's and Pacific white-sided dolphin clicks occurred more often at night (Fig. 9). This pattern has been reported previously for these species (Soldevilla et al. 2010b, 2010a) and is likely associated with the diel vertical migration of mesopelagic prey, as observed in other delphinid species (Benoit-Bird and Au 2003; Benoit-Bird et al. 2004). Because both Risso's and Pacific white-sided dolphins primarily prey on squid offshore of Washington (Norris and Prescott 1961; Stroud et al. 1981; Kenney and Winn 1986), we might expect some degree of habitat partitioning to reduce competition for resources. However, although we saw a possible preference for different habitats, we did not see a clear spatial or temporal separation of these species: manual detections were highest for both species during summer, Pacific whitesided dolphin manual detections were highest at Slope, and, although Risso's dolphin manual detections were highest at Canyon, Pacific white-sided dolphin clicks were, in fact, more prevalent at this site (Fig. 7). Since these species seem to overlap while feeding offshore of Washington, they may be preying upon different species. Pacific white-sided dolphins prey on fish in addition to squid in other regions (Norris and Prescott 1961) and are reported to do so opportunistically offshore of Washington (Stroud et al. 1981).

The presence of this nocturnal pattern in Pacific whitesided dolphin clicks, as well as the increase in manual detections during summer (Fig. 7), also supports hypotheses about the behavior and movements of different subpopulations of Pacific white-sided dolphins in the North Pacific. Offshore of California, two populations of Pacific white-sided dolphins can presumably be acoustically discriminated (Walker et al. 1986, Soldevilla et al. 2008, 2010b, Henderson et al. 2011), and the California/Oregon/Washington subpopulation is believed to move between California in the winter and Oregon/Washington in the summer (Walker et al. 1986, Green et al. 1992, Forney and Barlow 1998). This population produces clicks more often at night (Soldevilla et al. 2010b), which may indicate that the detections we report are from this northward-southward moving subpopulation. However, there is also evidence that Pacific white-sided dolphins may undergo inshore-offshore movement throughout the year (Green et al. 1992, Soldevilla et al. 2010b, Kanes 2018). A better delineation of subpopulations for Risso's and Pacific white-sided dolphins in the North Pacific, which may be possible using acoustic discrimination (Soldevilla et al. 2010b), would likely further our understanding of the more fine-scale movements of these species.

\section{Beaked whales}

Although beaked whales exhibited temporal separation from other odontocete species, manually validated detections of all beaked whale species occurred primarily in the winter and spring (Fig. 10). In the Gulf of Alaska, Stejneger's and Cuvier's beaked whales showed spatial separation, with Stejneger's clicks highest along the continental slope while Cuvier's clicks were highest at an offshore seamount and were almost absent at the slope (Rice et al. 2021). Additionally, during visual surveys offshore of Washington, Cuvier's beaked whales were typically sighted farther offshore than Stejneger's beaked whales (Barlow and Forney 2007, Moore and Barlow 2013) and acoustic detections of Cuvier's beaked whales offshore of Oregon were higher than detections of Stejneger's beaked whales (Simonis et al. 2020). Since we did not have a site farther offshore than Canyon, we may not have successfully captured the distribution of Cuvier's beaked whales offshore of Washington, possibly explaining the low level of Cuvier's beaked whale manually validated detections. This may also be true for the possible Hubbs' beaked whale (BW37V) click type since it was detected in even lower numbers offshore of Washington and 
previous detections of this click type along the U.S. west coast occurred in deeper water than site Canyon (Griffiths et al. 2018; Simonis et al. 2020, Table S1).

The lack of manually validated beaked whale detections during the summer months is interesting, as the year-round distribution of beaked whales is still not well understood. For Cuvier's beaked whales, a similar seasonal pattern was found in the Gulf of Alaska (Rice et al. 2021) and offshore of Southern California (Baumann-Pickering et al. 2014), with manually validated detections decreasing in the late summer. Meanwhile, in the Gulf of Alaska, Stejneger's beaked whales were recorded year-round and clicks peaked in the fall (Rice et al. 2021). Whether the lack of clicks offshore of Washington during summer is due to a change in behavior or to these species moving to a different area to forage is currently unknown. Since beaked whales inhabit pelagic waters and are difficult to visually observe, acoustic surveys can greatly increase our knowledge of these cryptic species. However, there is a need for more extensive acoustic surveys in offshore waters, as knowledge of the more fine-scale distribution of beaked whale species is still quite limited. This is especially warranted since beaked whale abundance has fluctuated in the last few decades (Moore and Barlow 2013, 2017) and the current status of these populations is unknown (Carretta et al. 2019).

\section{Conclusion}

In this study, we used passive acoustic monitoring to examine the spatial and temporal distributions of ten cetacean species off the coast of Washington. Seasonal patterns were evident for all species except minke whales, for which manually validated detections were rare. For mysticetes, increased detections during the fall and winter are likely related to reproduction-associated calling, whereas, for odontocetes, seasonal changes in click detections are likely related to the presence of prey. Risso's and Pacific white-sided dolphins were also the only species for which a diel pattern was found, as clicks occurred more often at night.

On a small scale, we were able to investigate how acoustic presence varied between the continental shelf, slope, and a submarine canyon, and found that the two sites farther offshore had higher acoustic presence. In other regions, submarine canyons are important foraging habitats for many cetacean species (Moors-Murphy 2014, Fernandez-Arcaya et al. 2017) and all species examined in this study had acoustic presence at site Canyon. This highlights the significance of adequately surveying such habitats, as well as other offshore regions, so that conservation strategies accurately reflect current cetacean distributions.

On a large scale, many of the seasonal patterns we detected, such as for blue and sperm whales, as well as
Risso's and Pacific white-sided dolphins, seem to corroborate findings in other regions and support hypotheses about the movements of these populations. Additionally, we found interannual changes in detections for most of the large whale species we examined, which corresponded with changes in oceanographic conditions. While it is important to understand the habitat use and behavior of cetaceans offshore of Washington, it is also necessary to understand how these same populations utilize other regions, as well as the factors that may impact their distribution.

Although many of our findings support those of previous research in the region, there is a need for continued visual and acoustic surveys in areas utilized by marine mammals to better understand changes and impacts caused by sources such as climate change and anthropogenic sounds. It is the use of these surveys, in combination, over large temporal and spatial scales that will be able to inform successful conservation strategies.

Supplementary Information The online version contains supplementary material available at https://doi.org/10.1007/s00227-021-03941-9.

Acknowledgments The authors acknowledge the Chief of Naval Operations N45 Living Marine Resources Program (Frank Stone and Ernie Young) and U.S. Pacific Fleet (Chip Johnson) for the funding of this study. Support was also provided by the Naval Postgraduate School (Curt Collins and John Joseph). We thank Hannah Basset, Chris Garsha, Ryan Griswold, Brent Hurley, Bruce Thayre, John Hurwitz, and Erin O'Neill for coordinating instrument deployment, recovery, and data processing. We also thank Arial Brewer and Rachel Gottlieb for contributing to data analysis, Marie Roch for the development of the Tethys database used for storing metadata and generating figures, the Cascadia Research Collective (John Calambokidis, Erin Falcone, and Greg Schorr) for visual survey data collected 2004-2008, and two anonymous reviewers for providing comments to improve the manuscript. We acknowledge the use of the Maptool program for the generation of Fig. 1, Maptool is a product of seaturtle.org. This research was conducted in the Olympic Coast National Marine Sanctuary under permits OCNMS-2006-003-(A1, A2, A3) and OCNMS-2010-010-(A1), and we thank Mary Sue Brancato and Liam Antrim for their assistance.

Author contributions AŠ, EMO, SMW, JAH, and SBP contributed to the study conception, design, and management. AR, AJD, EMO, JST, and LMV performed data analysis. A $\breve{S}$ and SBP contributed to code development and modeling for data analysis. AR generated all tables and figures. The first draft of the manuscript was written by AR and all authors commented on previous versions of the manuscript. All authors read and approved the final manuscript.

Funding This study was supported by funding from the Chief of Naval Operations N45 Living Marine Resources Program, the U.S. Pacific Fleet, and the Naval Postgraduate School.

Availability of data and materials Metadata analyzed during this study are available via the Tethys database from the corresponding author on reasonable request. 


\section{Declarations}

Conflicts of interest The authors declare that they have no conflict of interest.

Ethical approval This research was conducted in the Olympic Coast National Marine Sanctuary under permits OCNMS-2006-003-(A1, A2, A3) and OCNMS-2010-010-(A1).

Informed consent Not applicable.

Consent for publication Not applicable.

Open Access This article is licensed under a Creative Commons Attribution 4.0 International License, which permits use, sharing, adaptation, distribution and reproduction in any medium or format, as long as you give appropriate credit to the original author(s) and the source, provide a link to the Creative Commons licence, and indicate if changes were made. The images or other third party material in this article are included in the article's Creative Commons licence, unless indicated otherwise in a credit line to the material. If material is not included in the article's Creative Commons licence and your intended use is not permitted by statutory regulation or exceeds the permitted use, you will need to obtain permission directly from the copyright holder. To view a copy of this licence, visit http://creativecommons.org/licenses/by/4.0/.

\section{References}

Au WWL, Mobley J, Burgess WC, Lammers MO, Nachtigall PE (2000) Seasonal and diurnal trends of chorusing humpback whales wintering in waters off western Maui. Mar Mamm Sci 16:530-544. https://doi.org/10.1111/j.1748-7692.2000.tb00949.x

Aulich MG, McCauley RD, Saunders BJ, Parsons MJG (2019) Fin whale (Balaenoptera physalus) migration in Australian waters using passive acoustic monitoring. Sci Rep 9:12. https://doi.org/ 10.1038/s41598-019-45321-w

Bailey H, Mate BR, Palacios DM, Irvine L, Bograd SJ, Costa DP (2009) Behavioural estimation of blue whale movements in the Northeast Pacific from state-space model analysis of satellite tracks. Endanger Species Res 10:93-106. https://doi.org/10.3354/ esr00239

Baker CS, Herman LM (1984) Aggressive behavior between humpback whales (Megaptera novaeangliae) wintering in Hawaiian waters. Can J Zool 62:1922-1937. https://doi.org/10.1139/z84-282

Barlow J, Forney KA (2007) Abundance and population density of cetaceans in the California Current ecosystem. Fish Bull 105:509-526

Barlow J, Taylor BL (2005) Estimates of sperm whale abundance in the northeastern temperate Pacific from a combined acoustic and visual survey. Mar Mamm Sci 21:429-445. https://doi.org/10. 1111/j.1748-7692.2005.tb01242.x

Barlow J, Calambokidis J, Falcone EA, Baker CS, Burdin AM, Clapham PJ, Ford JKB, Gabriele CM, LeDuc R, Mattila DK, Quinn TJ, Rojas-Bracho L, Straley JM, Taylor BL, Urban J, Wade P, Weller D, Witteveen BH, Yamaguchi M (2011) Humpback whale abundance in the North Pacific estimated by photographic capture-recapture with bias correction from simulation studies. Mar Mamm Sci 27:793-818. https://doi.org/10.1111/j. 1748-7692.2010.00444.x

Baumann-Pickering S, McDonald MA, Simonis AE, Berga AS, Merkens KPB, Oleson EM, Roch MA, Wiggins SM, Rankin S, Yack
TM, Hildebrand JA (2013a) Species-specific beaked whale echolocation signals. J Acoust Soc Am 134:2293-2301. https://doi. org/10.1121/1.4817832

Baumann-Pickering S, Simonis AE, Wiggins SM, Brownell RL, Hildebrand JA (2013b) Aleutian Islands beaked whale echolocation signals. Mar Mamm Sci 29:221-227. https://doi.org/10.1111/j. 1748-7692.2011.00550.x

Baumann-Pickering S, Roch MA, Brownell RL, Simonis AE, McDonald MA, Solsona-Berga A, Oleson EM, Wiggins SM, Hildebrand JA (2014) Spatio-temporal patterns of beaked whale echolocation signals in the North Pacific. PLoS ONE 9:17. https://doi.org/10.1371/journal.pone.0086072

Benoit-Bird KJ, Au WWL (2003) Prey dynamics affect foraging by a pelagic predator (Stenella longirostris) over a range of spatial and temporal scales. Behav Ecol Sociobiol 53:364-373. https:// doi.org/10.1007/s00265-003-0585-4

Benoit-Bird KJ, Wursig B, McFadden CJ (2004) Dusky dolphin (Lagenorhynchus obscurus) foraging in two different habitats: active acoustic detection of dolphins and their prey. Mar Mamm Sci 20:215-231. https://doi.org/10.1111/j.1748-7692. 2004.tb01152.x

Bettridge S, Baker CS, Barlow J, Clapham PJ, Ford M, Gouveia D, Mattila DK, Pace RM III, Rosel PE, Silber GK, Wade PR (2015) Status review of the humpback whale (Megaptera novaeangliae) under the Endangered Species Act. NOAA Techl Mem NMFS-SWFSC 540:1-240

Bjorkstedt EP, Goericke R, McClatchie S, Weber E, Watson W, Lo N, Peterson B, Emmett B, Brodeur R, Peterson J, Litz M, GomezValdez J, Gaxiola-Castro G, Lavaniegos B, Chavez F, Collins CA, Field J, Sakuma K, Warzybok P, Bradley R, Jahncke J, Bograd S, Schwing F, Campbell GS, Hildebrand J, Sydeman W, Thompson SA, Largier JL, Halle C, Kim SY, Abell J (2011) State of the California Current 2010-2011: regionally variable responses to a strong (but fleeting?) La Nina? Calif Coop Ocean Fish Invest Rep 52:36-68

Burnham RE, Duffus DA, Ross T (2021) Remote sensing and mapping habitat features pertinent to fin whale life histories in coastal and offshore waters of Vancouver Island, British Columbia. J Exp Mar Biol Ecol 537:1-11

Calambokidis J, Barlow J (2004) Abundance of blue and humpback whales in the eastern North Pacific estimated by capturerecapture and line-transect methods. Mar Mamm Sci 20:63-85. https://doi.org/10.1111/j.1748-7692.2004.tb01141.x

Calambokidis J, Barlow J (2020) Updated abundance estimates for blue and humpback whales along the U.S. West Coast using data through 2018, U.S. Department of Commerce, NOAA Technical Memorandum NMFS-SWFSC-634

Calambokidis J, Steiger GH, Ellifrit DK, Troutman BL, Bowlby CE (2004) Distribution and abundance of humpback whales (Megaptera novaeangliae) and other marine mammals off the northern Washington coast. Fish Bull 102:563-580

Calambokidis J, Barlow J, Ford JKB, Chandler TE, Douglas AB (2009) Insights into the population structure of blue whales in the Eastern North Pacific from recent sightings and photographic identification. Mar Mamm Sci 25:816-832. https://doi. org/10.1111/j.1748-7692.2009.00298.x

Calambokidis J, Steiger GH, Curtice C, Harrison J, Ferguson MC, Becker E, DeAngelis M, Van Parijs SM (2015) Biologically important areas for selected cetaceans within US waters-west coast region. Aquat Mamm 41:39-53. https://doi.org/10.1578/ am.41.1.2015.39

Calambokidis J, Barlow J, Flynn K, Dobson E, Steiger GH (2017) Update on abundance, trends, and migrations of humpback whales along the US West Coast. IWC Report SC/A17/NP/13 for the Workshop on the Comprehensive Assessment of North 
Pacific Humpback Whales. Seattle, WA 18-21. Accessed on April 2017.

Carretta JV, Forney KA, Oleson EM, Weller EM, Lang AR, Baker J, Muto MM, Hanson B, Orr AJ, Huber H, Lowry MS, Barlow J, Moore JE, Lynch D, Carswell L, Brownell RLJ (2019) U.S. Pacific marine mammal stock assessments: 2018. U.S. Department of Commerce, NOAA Tech. Memo. NMFS-SWFSC-617

Carretta JV, Forney KA, Oleson EM, Weller DW, Lang AR, Baker J, Muto MM, Hanson B, Orr AJ, Huber H, Lowry MS, Barlow J, J.E. M, Lynch D, Carswell L, Brownell RLJ (2020) U.S. Pacific marine mammal stock assessments: 2019. U.S. Department of Commerce, NOAA Tech. Memo. NMFS-SWFSC-629

Castellote M, Clark CW, Lammers MO (2012) Fin whale (Balaenoptera physalus) population identity in the western Mediterranean Sea. Mar Mamm Sci 28:325-344. https://doi.org/10.1111/j.17487692.2011.00491.x

Clark CW, Clapham PJ (2004) Acoustic monitoring on a humpback whale (Megaptera novaeangliae) feeding ground shows continual singing into late spring. Proc R Soc B-Biol Sci 271:1051-1057. https://doi.org/10.1098/rspb.2004.2699

Croll DA, Clark CW, Acevedo A, Tershy B, Flores S, Gedamke J, Urban J (2002) Only male fin whales sing loud songs. Nature 417:809-809. https://doi.org/10.1038/417809a

Delarue J, Martin B, Hannay D (2013) Minke whale boing sound detections in the northeastern Chukchi Sea. Mar Mamm Sci 29:E333E341. https://doi.org/10.1111/j.1748-7692.2012.00611.x

Diogou N, Palacios DM, Nieukirk SL, Nystuen JA, Papathanassiou E, Katsanevakis S, Klinck H (2019) Sperm whale (Physeter macrocephalus) acoustic ecology at Ocean Station PAPA in the Gulf of Alaska-part 1: Detectability and seasonality. Deep-Sea Res Part I-Oceanogr Res Pap 150:14. https://doi.org/10.1016/j.dsr. 2019.05.007

Dorsey EM, Stern SJ, Hoelzel AR, Jacobsen J (1990) Minke whales (Balaenoptera acutorostrata) from the West Coast of North America: Individual recognition and small-scale site fidelity. Rep Int Whal Comm Spec Iss 12:357-368

Dunlop RA, Noad MJ, Cato DH, Stokes D (2007) The social vocalization repertoire of east Australian migrating humpback whales (Megaptera novaeangliae). J Acoust Soc Am 122:2893-2905. https://doi.org/10.1121/1.2783115

Fernandez-Arcaya U, Ramirez-Llodra E, Aguzzi J, Allcock AL, Davies JS, Dissanayake A, Harris P, Howell K, Huvenne VAI, Macmillan-Lawler M, Martin J, Menot L, Nizinski M, Puig P, Rowden AA, Sanchez F, Van den Beld IMJ (2017) Ecological role of submarine canyons and need for canyon conservation: a review. Front Mar Sci 4:26. https://doi.org/10.3389/fmars.2017.00005

Flinn RD, Trites AW, Gregr EJ, Perry RI (2002) Diets of fin, sei, and sperm whales in British Columbia: an analysis of commercial whaling records, 1963-1967. Mar Mamm Sci 18:663-679. https://doi.org/10.1111/j.1748-7692.2002.tb01065.x

Ford JKB, Ellis GA, Matkin DR, Balcomb KC, Briggs D, Morton AB (2005) Killer whale attacks on minke whales: prey capture and antipredator tactics. Mar Mamm Sci 21:603-618. https://doi.org/ 10.1111/j.1748-7692.2005.tb01254.x

Forney KA (2007) Preliminary estimates of cetacean abundance along the U.S. West Coast and within four national marine sanctuaries during 2005. NOAA Tech Mem NMFS-SWFSC 406:1-27

Forney KA, Barlow J (1998) Seasonal patterns in the abundance and distribution of California cetaceans, 1991-1992. Mar Mamm Sci 14:460-489. https://doi.org/10.1111/j.1748-7692.1998.tb00737.x

Fournet ME, Szabo A, Mellinger DK (2015) Repertoire and classification of non-song calls in Southeast Alaskan humpback whales (Megaptera novaeangliae). J Acoust Soc Am 137:1-10. https:// doi.org/10.1121/1.4904504
Fournet MEH, Matthews LP, Gabriele CM, Mellinger DK, Klinck H (2018) Source levels of foraging humpback whale calls. J Acoust Soc Am. https://doi.org/10.1121/1.5023599

Gabriele CM, Frankel AS (2002) The occurrence and significance of humpback whale songs in Glacier Bay, Southeastern Alaska. Arctic Res 16:42-47

Garland EC, Gedamke J, Rekdahl ML, Noad MJ, Garrigue C, Gales N (2013) Humpback whale song on the Southern Ocean feeding grounds: implications for cultural transmission. PLoS ONE 8:9. https://doi.org/10.1371/journal.pone.0079422

Green GA, Brueggman JJ, Grotefendt RA, Bowlby CE, Bonnell ML, Balcomb KC (1992) Cetacean distribution and abundance off Oregon and Washington, 1989-1990. In: Brueggeman JJ (ed) Oregon and Washington marine mammal and seabird surveys. Ebasco Environmental, Bellvue, WA, pp 1-100

Green GA, Grotefendt RA, Smultea MA, Bowlby CE, Rowlett RA (1993) Delphinid aerial surveys in Oregon and Washington offshore waters. Ebasco Environmental, National Marine Fisheries Service, National Marine Mammal Laboratory.

Gregr EJ, Nichol L, Ford JKB, Ellis G, Trites AW (2000) Migration and population structure of northeastern Pacific whales off coastal British Columbia: an analysis of commercial whaling records from 1908-1967. Mar Mamm Sci 16:699-727. https:// doi.org/10.1111/j.1748-7692.2000.tb00967.x

Griffiths ET, Keating JL, Barlow J, Moore JE (2018) Description of a new beaked whale echolocation pulse type in the California Current. Mar Mamm Sci 35:1058-1069. https://doi.org/10. $1111 / \mathrm{mms} .12560$

Hanson MB, Emmons CK, Ward EJ, Nystuen JA, Lammers MO (2013) Assessing the coastal occurrence of endangered killer whales using autonomous passive acoustic recorders. J Acoust Soc Am 134:3486-3495. https://doi.org/10.1121/1.4821206

Helble TA, Ierley GR, D’Spain GL, Roch MA, Hildebrand JA (2012) A generalized power-law detection algorithm for humpback whale vocalizations. J Acoust Soc Am 131:2682-2699. https:// doi.org/10.1121/1.3685790

Helble TA, D'Spain GL, Campbell GS, Hildebrand JA (2013) Calibrating passive acoustic monitoring: Correcting humpback whale call detections for site-specific and time-dependent environmental characteristics. J Acoust Soc Am. https://doi. org/10.1121/1.4822319

Helble TA, Guazzo RA, Alongi GC, Martin CR, Martin SW, Henderson EE (2020) Fin whale song patterns shift over time in the Central North Pacific. Front Mar Sci 7:16. https://doi.org/ 10.3389/fmars.2020.587110

Henderson EE, Hildebrand JA, Smith MH (2011) Classification of behavior using vocalizations of Pacific white-sided dolphins (Lagenorhynchus obliquidens). J Acoust Soc Am 130:557-567. https://doi.org/10.1121/1.3592213

Henderson EE, Helble TA, Ierley GR, Martin SW (2018) Identifying behavioral states and habitat use of acoustically tracked humpback whales in Hawaii. Mar Mamm Sci 34:1-17. https:// doi.org/10.1111/mms.12475

Herman LM (2017) The multiple functions of male song within the humpback whale (Megaptera novaeangliae) mating system: review, evaluation, and synthesis. Biol Rev 92:1795-1818. https://doi.org/10.1111/brv.12309

Herman LM, Pack AA, Spitz SS, Herman EYK, Rose K, Hakala S, Deakos MH (2013) Humpback whale song: who sings? Behav Ecol Sociobiol 67:1653-1663. https://doi.org/10.1007/ s00265-013-1576-8

Hoelzel AR, Dorsey EM, Stern SJ (1989) The foraging specializations of individuals minke whales. Anim Behav 38:786-794. https://doi.org/10.1016/s0003-3472(89)80111-3 
Huyer A, Sobey EJC, Smith RL (1979) Spring transition in currents over the Oregon continental shelf. J Geophys Res-Oceans 84:6995-7011. https://doi.org/10.1029/JC084iC11p06995

Johnson M, Madsen PT, Zimmer WMX, de Soto NA, Tyack PL (2004) Beaked whales echolocate on prey. Proc R Soc B-Biol Sci 271:S383-S386. https://doi.org/10.1098/rsbl.2004.0208

Kanes KSJ (2018) Temporal patterns in Pacific white-sided dolphin pulsed calls at Barkley Canyon, with implications for multiple populations. Master's Thesis, University of Victoria.

Keating JL, Barlow J, Griffiths ET, Moore JE (2016) Passive acoustic survey of cetacean abundance levels (PASCAL-2016) Final Report. Honolulu (HI): US Department of the Interior, Bureau of Ocean Energy Management OCS Study BOEM 2018-025 $22 \mathrm{p}$

Keiper CA, Ainley DG, Allen SG, Harvey JT (2005) Marine mammal occurrence and ocean climate off central California, 1986 to 1994 and 1997 to 1999. Mar Ecol Prog Ser 289:285-306. https://doi.org/10.3354/meps289285

Kenney RD, Winn HE (1986) Cetacean high-use habitats of the Northeast United States continental shelf. Fish Bull 84:345-357

Koot B (2015) Winter behaviour and population structure of fin whales (Balaenoptera physalus) in British Columbia inferred from passive acoustic data. Master's Thesis, The University of British Columbia

Kowarski KA, Moors-Murphy H (2020) A review of big data analysis methods for baleen whale passive acoustic monitoring. Mar Mamm Sci. https://doi.org/10.1111/mms.12758

Kowarski K, Evers C, Moors-Murphy H, Martin B, Denes SL (2018) Singing through winter nights: Seasonal and diel occurrence of humpback whale (Megaptera novaeangliae) calls in and around the Gully MPA, offshore eastern Canada. Mar Mamm Sci 34:169-189. https://doi.org/10.1111/mms.12447

Lewis LA, Calambokidis J, Stimpert AK, Fahlbusch J, Friedlaender AS, McKenna MF, Mesnick SL, Oleson EM, Southall BL, Szesciorka AR, Širović A (2018) Context-dependent variability in blue whale acoustic behaviour. R Soc Open Sci 5:20. https://doi. org/10.1098/rsos. 180241

Lilly LE, Ohman MD (2018) CCE IV: El Nino-related zooplankton variability in the southern California Current System. DeepSea Res Part I-Oceanogr Res Pap 140:36-51. https://doi.org/10. 1016/j.dsr.2018.07.015

Madsen PT, Wahlberg M, Mohl B (2002) Male sperm whale (Physeter macrocephalus) acoustics in a high-latitude habitat: implications for echolocation and communication. Behav Ecol Sociobiol 53:31-41. https://doi.org/10.1007/s00265-002-0548-1

Madsen PT, Kerr I, Payne R (2004) Echolocation clicks of two freeranging, oceanic delphinids with different food preferences: false killer whales Pseudorca crassidens and Risso's dolphins Grampus griseus. J Exp Biol 207:1811-1823. https://doi.org/10.1242/ jeb.00966

Mattila DK, Guinee LN, Mayo CA (1987) Humpback whale songs on a North Atlantic feeding ground. J Mammal 68:880-883. https:// doi.org/10.2307/1381574

McDonald MA, Calambokidis J, Teranishi AM, Hildebrand JA (2001) The acoustic calls of blue whales off California with gender data. J Acoust Soc Am 109:1728-1735. https://doi.org/10.1121/1. 1353593

McDonald MA, Mesnick SL, Hildebrand JA (2006) Biogeographic characterisation of blue whale song worldwide: using song to identify populations. J Cetacean Res Manag 8:55-65

McDonald MA, Hildebrand JA, Mesnick S (2009) Worldwide decline in tonal frequencies of blue whale songs. Endanger Species Res 9:13-21. https://doi.org/10.3354/esr00217

McSweeney DJ, Chu KC, Dolphin WF, Guinee LN (1989) North Pacific humpback whale songs: a comparison of southeast
Alaskan feeding ground songs with Hawaiian wintering ground songs. Mar Mamm Sci 5:139-148. https://doi.org/10.1111/j. 1748-7692.1989.tb00328.x

Mellinger DK, Clark CW (2000) Recognizing transient low-frequency whale sounds by spectrogram correlation. J Acoust Soc Am 107:3518-3529. https://doi.org/10.1121/1.429434

Mellinger DK, Stafford KM, Fox CG (2004) Seasonal occurrence of sperm whale (Physeter macrocephalus) sounds in the Gulf of Alaska, 1999-2001. Mar Mamm Sci 20:48-62. https://doi.org/ 10.1111/j.1748-7692.2004.tb01140.x

Mellinger DK, Stafford KM, Moore SE, Dziak RP, Matsumoto H (2007) An overview of fixed passive acoustic observation methods for cetaceans. Oceanography 20:36-45. https://doi.org/10. 5670/oceanog.2007.03

Mizroch SA, Rice DW, Zwiefelhofer D, Waite J, Perryman WL (2009) Distribution and movements of fin whales in the North Pacific Ocean. Mamm Rev 39:193-227. https://doi.org/10.1111/j.13652907.2009.00147.x

Møhl B, Wahlberg M, Madsen PT, Heerfordt A, Lund A (2003) The monopulsed nature of sperm whale clicks. J Acoust Soc Am 114:1143-1154. https://doi.org/10.1121/1.1586258

Monnahan CC, Branch TA, Stafford KM, Ivashchenko YV, Oleson EM (2014) Estimating historical eastern North Pacific blue whale catches using spatial calling patterns. PLoS ONE 9:21. https:// doi.org/10.1371/journal.pone.0098974

Moore JE, Barlow JP (2013) Declining abundance of beaked whales (Family Ziphiidae) in the California Current Large Marine Ecosystem. PLoS ONE 8:12. https://doi.org/10.1371/journal.pone. 0052770

Moore J, Barlow J (2017) Population abundance and trend estimates for beaked whales and sperm whales in the California Current from ship-based visual line-transect survey data 1991-2014. NOAA Tech Mem NMFS-SWFSC 585:16

Moore SE, Stafford KM, Dahlheim ME, Fox CG, Braham HW, Polovina JJ, Bain DE (1998) Seasonal variation in reception of fin whale calls at five geographic areas in the north Pacific. Mar Mamm Sci 14:617-627. https://doi.org/10.1111/j.1748-7692. 1998.tb00749.x

Moors-Murphy HB (2014) Submarine canyons as important habitat for cetaceans, with special reference to the Gully: a review. DeepSea Res Part II-Top Stud Oceanogr 104:6-19. https://doi.org/10. 1016/j.dsr2.2013.12.016

Nieukirk SL, Mellinger DK, Moore SE, Klinck K, Dziak RP, Goslin J (2012) Sounds from airguns and fin whales recorded in the midAtlantic Ocean, 1999-2009. J Acoust Soc Am 131:1102-1112. https://doi.org/10.1121/1.3672648

Nikolich K, Towers JR (2020) Vocalizations of common minke whales (Balaenoptera acutorostrata) in an eastern North Pacific feeding ground. Bioacoustics 29:97-108. https://doi.org/10.1080/09524 622.2018 .1555716

NOAA (2016) Endangered and threatened species; Identification of 14 distinct populations segments of the humpback whale ( $\mathrm{Meg}$ aptera novaeangliae) and revision of species-wide listing. Fed Reg 81:62260-62320

Norris KS, Prescott JH (1961) Observations on Pacific cetaceans of California and Mexican waters. Univ Calif Publ Zool 63:291-401

Norris TF, Mc Donald M, Barlow J (1999) Acoustic detections of singing humpback whales (Megaptera novaeangliae) in the eastern North Pacific during their northbound migration. J Acoust Soc Am 106:506-514. https://doi.org/10.1121/1.427071

Oleson EM, Calambokidis J, Burgess WC, McDonald MA, LeDuc CA, Hildebrand JA (2007a) Behavioral context of call production by eastern North Pacific blue whales. Mar Ecol Prog Ser 330:269-284. https://doi.org/10.3354/meps330269

Oleson EM, Wiggins SM, Hildebrand JA (2007b) Temporal separation of blue whale call types on a southern California feeding 
ground. Anim Behav 74:881-894. https://doi.org/10.1016/j. anbehav.2007.01.022

Oleson EM, Calambokidis J, Falcone E, Schorr G, Hildebrand JA (2009) Acoustic and visual monitoring of cetaceans along the outer Washington coast. Naval Postgraduate School Report NPS-OC-09-001

Oleson EM, Slrovic A, Bayless AR, Hildebrand JA (2014) Synchronous seasonal change in fin whale song in the North Pacific. PLoS ONE 9:18. https://doi.org/10.1371/journal.pone.0115678

Payne RS, McVay S (1971) Songs of humpback whales. Science 173:585-597. https://doi.org/10.1126/science.173.3997.585

Peterson WT, Fisher JL, Strub PT, Du XN, Risien C, Peterson J, Shaw CT (2017) The pelagic ecosystem in the Northern California Current off Oregon during the 2014-2016 warm anomalies within the context of the past 20 years. J Geophys Res-Oceans 122:7267-7290. https://doi.org/10.1002/2017jc012952

Peterson WT, Fisher JL, Morgan CA, Zeman SM, Burke BJ, Jacobson KC (2019) Ocean ecosystem indicators of salmon marine survival in the Northern California Current. NOAA, Northwest Fisheries Science Center, pp 1-97

Porter MB (2011) The BELLHOP manual and user's guide: PRELIMINARY DRAFT. Heat, Light, and Sound Research, Inc., La Jolla, CA, USA, Tech Rep

R Core Team (2020) R: A language and environment for statistical computing. R Foundation for Statistical Computing, Vienna, Austria

Rankin S, Barlow J (2005) Source of the North Pacific "boing" sound attributed to minke whales. J Acoust Soc Am 118:3346-3351. https://doi.org/10.1121/1.2046747

Rankin S, Barlow J, Oswald J, Ballance L (2008) Acoustic studies of marine mammals during seven years of combined visual and acoustic line-transect surveys for cetaceans in the Eastern and Central Pacific Ocean. NOAA Technical Memorandum NMFS-SWFSC-429

Rekdahl M, Tisch C, Cerchio S, Rosenbaum H (2017) Common nonsong social calls of humpback whales (Megaptera novaeangliae) recorded off northern Angola, southern Africa. Mar Mamm Sci 33:365-375. https://doi.org/10.1111/mms.12355

Rice A, Deecke VB, Ford JKB, Pilkington JF, Oleson EM, Hildebrand JA, Sirovic A (2017) Spatial and temporal occurrence of killer whale ecotypes off the outer coast of Washington State, USA. Mar Ecol Prog Ser 572:255-268. https://doi.org/10.3354/meps1 2158

Rice A, Širović A, Trickey JS, Debich AJ, Gottlieb RS, Wiggins SM, Hildebrand JA, Baumann-Pickering S (2021) Cetacean occurrence in the Gulf of Alaska from long-term passive acoustic monitoring. Mar Biol 168:1-29. https://doi.org/10.1007/ s00227-021-03884-1

Risch D, Castellote M, Clark CW, Davis GE, Dugan PJ, Hodge LEW, Kumar A, Lucke K, Mellinger DK, Nieukirk SL, Popescu CM, Ramp C, Read AJ, Rice AN, Silva MA, Siebert U, Stafford KM, Verdaat H, Van Parijs SM (2014) Seasonal migrations of North Atlantic minke whales: novel insights from large-scale passive acoustic monitoring networks. Mov Ecol 2:17. https://doi.org/10. 1186/s40462-014-0024-3

Roch MA, Klinck H, Baumann-Pickering S, Mellinger DK, Qui S, Soldevilla MS, Hildebrand JA (2011) Classification of echolocation clicks from odontocetes in the Southern California Bight. J Acoust Soc Am 129:467-475. https://doi.org/10.1121/1.3514383

Rocha RC Jr, Clapham PJ, Ivashchenko YV (2014) Emptying the oceans: A summary of industrial whaling catches in the 20th century. US Natl Mar Fish Serv Mar Fish Rev 76:37-48

Santora JA, Zeno R, Dorman JG, Sydeman WJ (2018) Submarine canyons represent an essential habitat network for krill hotspots in a large marine ecosystem. Sci Rep 8:9. https://doi.org/10.1038/ s41598-018-25742-9
Schorr GS, Falcone EA, Calambokidis J, Andrews RD (2010) Satellite tagging of fin whales off California and Washington in 2010 to identify movement patterns, habitat use, and possible stock boundaries. Report prepared by Cascadia Research Collective for SWFSC, NMFS

Simonis AE, Trickey JS, Barlow J, Rankin S, Urban J, Rojas-Bracho L, Moore JE (2020) Passive acoustic survey of deep-diving odontocetes in the California Current Ecosystem 2018: Final report, U.S. Department of Commerce, NOAA Technical Memorandum NMFS-SWFSC-630: 1-48

Širović A (2016) Variability in the performance of the spectrogram correlation detector for North-east Pacific blue whale calls. Bioacoustics 25:145-160. https://doi.org/10.1080/09524622.2015. 1124248

Širović A, Hildebrand JA, Wiggins SM, McDonald MA, Moore SE, Thiele D (2004) Seasonality of blue and fin whale calls and the influence of sea ice in the Western Antarctic Peninsula. DeepSea Res Part II-Top Stud Oceanogr 51:2327-2344. https://doi. org/10.1016/j.dsr2.2004.08.005

Širović A, Hildebrand JA, Wiggins SM, Thiele D (2009) Blue and fin whale acoustic presence around Antarctica during 2003 and 2004. Mar Mamm Sci 25:125-136. https://doi.org/10.1111/j. 1748-7692.2008.00239.x

Širović A, Williams LN, Kerosky SM, Wiggins SM, Hildebrand JA (2013) Temporal separation of two fin whale call types across the eastern North Pacific. Mar Biol 160:47-57. https://doi.org/ 10.1007/s00227-012-2061-z

Širović A, Rice A, Chou E, Hildebrand JA, Wiggins SM, Roch MA (2015) Seven years of blue and fin whale call abundance in the Southern California Bight. Endanger Species Res 28:61-76. https://doi.org/10.3354/esr00676

Širović A, Oleson EM, Buccowich J, Rice A, Bayless AR (2017) Fin whale song variability in southern California and the Gulf of California. Sci Rep 7:10126. https://doi.org/10.1038/ s41598-017-09979-4

Soldevilla MS, Henderson EE, Campbell GS, Wiggins SM, Hildebrand JA, Roch MA (2008) Classification of Risso's and Pacific white-sided dolphins using spectral properties of echolocation clicks. J Acoust Soc Am 124:609-624. https://doi.org/10. $1121 / 1.2932059$

Soldevilla MS, Wiggins SM, Hildebrand JA (2010a) Spatial and temporal patterns of Risso's dolphin echolocation in the Southern California Bight. J Acoust Soc Am 127:124-132. https://doi.org/ $10.1121 / 1.3257586$

Soldevilla MS, Wiggins SM, Hildebrand JA (2010b) Spatio-temporal comparison of Pacific white-sided dolphin echolocation click types. Aquat Biol 9:49-62. https://doi.org/10.3354/ab00224

Soldevilla MS, Baumann-Pickering S, Cholewiak D, Hodge LEW, Oleson EM, Rankin S (2017) Geographic variation in Risso's dolphin echolocation click spectra. J Acoust Soc Am 142:599-617. https://doi.org/10.1121/1.4996002

Soule DC, Wilcock WSD (2013) Fin whale tracks recorded by a seismic network on the Juan de Fuca Ridge, Northeast Pacific Ocean. J Acoust Soc Am 133:1751-1761. https://doi.org/10.1121/1. 4774275

Stafford KM, Nieukirk SL, Fox CG (2001) Geographic and seasonal variation of blue whale calls in the North Pacific. J Cetacean Res Manag 3:65-76

Stafford KM, Mellinger DK, Moore SE, Fox CG (2007) Seasonal variability and detection range modeling of baleen whale calls in the Gulf of Alaska, 1999-2002. J Acoust Soc Am 122:3378-3390. https://doi.org/10.1121/1.2799905

Stimpert AK, Au WWL, Parks SE, Hurst T, Wiley DN (2011) Common humpback whale (Megaptera novaeangliae) sound types for passive acoustic monitoring. J Acoust Soc Am 129:476-482. https:// doi.org/10.1121/1.3504708 
Stimpert AK, Peavey LE, Friedlaender AS, Nowacek DP (2012) Humpback whale song and foraging behavior on an Antarctic feeding ground. PLoS ONE 7:8. https://doi.org/10.1371/journal.pone. 0051214

Stroud RK, Fiscus CH, Kajimura H (1981) Food of the Pacific whitesided dolphin, Lagenorhynchus obliquidens, Dall's porpoise, Phocoenoides dalli, and Northern fur seal, Callorhinus ursinus, off California and Washington. Fish Bull 78:951-959

Thompson PO, Friedl WA (1982) A long term study of low frequency sounds from several species of whales off Oahu, Hawaii USA. Cetology: 1-19

Thompson PO, Cummings WC, Ha SJ (1986) Sounds, source levels, and associated behavior of humpback whales, southeast Alaska. J Acoust Soc Am 80:735-740. https://doi.org/10.1121/1.393947

Towers JR, McMillan CJ, Malleson M, Hildering J, Ford JKB, Ellis GM (2013) Seasonal movements and ecological markers as evidence for migration of common minke whales photo-identified in the eastern North Pacific. J Cetacean Res Manage 13:221-229

Tyack P (1981) Interactions between singing Hawaiian humpback whales and conspecifics nearby. Behav Ecol Sociobiol 8:105116. https://doi.org/10.1007/bf00300822

Vikingsson GA, Heide-Jorgensen MP (2015) First indications of autumn migration routes and destination of common minke whales tracked by satellite in the North Atlantic during 20012011. Mar Mamm Sci 31:376-385. https://doi.org/10.1111/mms. 12144

Vu E (2015) Habitat use of calling baleen whales in the southern California Current Ecosystem, Dissertation, University of California San Diego

Vu ET, Risch D, Clark CW, Gaylord S, Hatch LT, Thompson MA, Wiley DN, Van Parijs SM (2012) Humpback whale song occurs extensively on feeding grounds in the western North Atlantic Ocean. Aquat Biol 14:175-183. https://doi.org/10.3354/ab00390

Walker WA, Leatherwood S, Goodrich KR, Perrin WF, Stroud RK (1986) Geographical variation and biology of the Pacific whitesided dolphin, Lagenorhynchus obliquidens, in the north-eastern Pacific. In: Bryden MM, Harrison RJ (eds) Research on Dolphins. Clarendon Press, Oxford, pp 441-465

Wang L, Heaney K, Pangerc T, Theobald P, Robinson S, Ainslie M (2014) Review of underwater acoustic propagation models. NPL Report AC 12

Watkins WA (1981) Activities and underwater sounds of fin whales. Sci Rep Whales Res Inst Tokyo 33:83-118
Watkins WA, Tyack P, Moore KE, Bird JE (1987) The 20-Hz signals of finback whales (Balaenoptera physalus). J Acoust Soc Am 82:1901-1912. https://doi.org/10.1121/1.395685

Watkins WA, Daher MA, Reppucci GM, George JE, Martin DL, DiMarzio NA, Gannon DP (2000) Seasonality and distribution of whale calls in the North Pacific. Oceanography 13:62-67

Weirathmueller MJ, Stafford KM, Wilcock WSD, Hilmo RS, Dziak RP, Trehu AM (2017) Spatial and temporal trends in fin whale vocalizations recorded in the NE Pacific Ocean between 2003-2013. PLoS ONE 12:24. https://doi.org/10.1371/journal.pone.0186127

Whitehead H (2003) Sperm whales: Social evolution in the ocean. The University of Chicago Press, Chicago

Wiggins SM, Hildebrand JA (2007) High-frequency Acoustic Recording Package (HARP) for broad-band, long-term marine mammal monitoring. In: Symposium on underwater technology and workshop on scientific use of submarine cables and related technologies, vol. 1 and 2, p 594

Wild LA, Gabriele CM (2014) Putative contact calls made by humpback whales ( Megaptera novaeangliae ) in southeastern Alaska. Can Acoust 42:23-32

Winn HE, Winn LK (1978) The song of the humpback whale Megaptera novaeangliae in the West Indies. Mar Biol 47:97-114. https://doi.org/10.1007/bf00395631

Wood SN (2011) Fast stable restricted maximum likelihood and marginal likelihood estimation of semiparametric generalized linear models. J R Stat Soc Ser B-Stat Methodol 73:3-36. https://doi. org/10.1111/j.1467-9868.2010.00749.x

Zeh JM, Rekdahl ML, Rice AN, Clark CW, Rosenbaum HC (2020) Detections of humpback whale (Megaptera novaeangliae) vocalizations on an acoustic sensor in the New York Bight. Mar Mamm Sci. https://doi.org/10.1111/mms.12775

Zimmer WMX, Johnson MP, Madsen PT, Tyack PL (2005) Echolocation clicks of free-ranging Cuvier's beaked whales (Ziphius cavirostris). J Acoust Soc Am 117:3919-3927. https://doi.org/ $10.1121 / 1.1910225$

Publisher's Note Springer Nature remains neutral with regard to jurisdictional claims in published maps and institutional affiliations. 